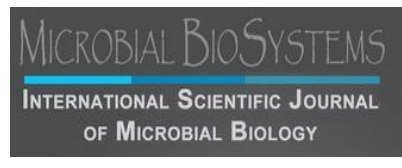

\title{
Beneficial fungal communities from different habitats and their roles in plant growth promotion and soil health

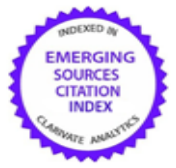

\author{
Devi $\mathbf{R}^{1}$, Kaur $\mathbf{T}^{1}$, Kour $\mathrm{D}^{1}$, Rana $\mathrm{KL}^{1}$, $\operatorname{Yadav} \mathrm{A}^{2}$ and $\operatorname{Yadav} \mathrm{AN}^{1^{*}}$ (]) \\ ${ }^{1}$ Department of Biotechnology, Dr. KSG Akal College of Agriculture, Eternal University, Sirmour, Himachal Pradesh, India \\ ${ }^{2}$ Department of Botany, Institute of Science, Banaras Hindu University, Varanasi, Uttar Pradesh, India
}

\begin{tabular}{l} 
ARTICLE INFO \\
\hline Article history \\
Received 16June 2020 \\
Received revised 29Ju \\
Accepted 29 June 2020 \\
Available online 30 Ju \\
@ Devi et al. 2020 \\
Corresponding Editor: \\
Abu-Elsaoud AM \\
Elkelish AA \\
Sridhar KR \\
Keywords \\
Antibiotics \\
Biofertilizers \\
Hydrolytic enzymes \\
Plant growth promotion \\
Plant growth regulators
\end{tabular}

\begin{abstract}
Microbes are ubiquitous in nature, and plant-microbe interactions are a key strategy for colonizing diverse habitats. Fungi are producing a wide range of secondary metabolites and bioactive compounds, which are probable alternative sources of drugs and/or antibiotics. Fungi are associated with the crops and plays an important role in plant growth promotion and enhanced soil fertility using different PGP mechanism such as solubilization of phosphorus, zinc, potassium; production of plant growth regulator (auxins, cytokinin, gibberellins, ethylene and abscisic acid); hydrolytic enzymes (xylanases, laccase, pectinases, cellulases); and siderophores. Besides eliciting plant defence reaction against pathogens; PGP fungi also help in plant growth promotion and alleviation of different abiotic stresses under harsh environments. The PGP fungi have reported from different genera of phyla Chytridiomycota, Zygomycota, Glomeromycota, Ascomycota, and Basidiomycota. Fungi also have significant potential applications in various industries like medical, and food. In the medical applications, fungi and fungal products are used to control disease in human and animals. In the fermentation industries fungi used to make alcoholic beverages, cheeses, bread, kefir, yogurt and various other food preparations and the agricultural sectors used to make plant healthy and protects to pathogens. The present review, deals with the biodiversity of beneficial fungi from different habitats and their biotechnological applications in plant growth promotion and soil health.
\end{abstract}

Published by Arab Society for Fungal Conservation

\section{Introduction}

Fungi are one of the most important taxonomic groups of microbes that exists on the whole world that is eukaryotic and heterotrophic living organism; including mildews, molds, mushroom, yeast and also puffballs. They are beneficial for plant growth and crop production as well as crop protections. Fungi have been reported from victorious soil, water, dead and decaying, organic matters and skin of animal's inhabitant that has high capacity and flexibility to uptake diverse undesirable or unfavourable conditions (Karun et al. 2018; Rana et al. 2019). They are found in different habitats such as water, soil, animals, dead matter, deserts and many are symbionts of plants but mostly grown in land environments but in which some species are growing aquatic habitats like (Deep oceans, seas and coral reefs, glaciers and hot spring) and as extreme environments (acidic, alkaline, drought, pressure, salinity, and temperatures) and associated with plants (epiphytic, endophytic, and rhizospheric) and human (Blanchette et al. 2017; Mouchacca 2016; Rashad and Abdel-Azeem 2017; Yadav et al. 2017a).

The beneficial fungi promotes the plant via directed multifarious plant growth-promoting (PGP) attributes including micronutrients solubilization (phosphorus, potassium and zinc), and production of plant growth regulators like auxin, gibberellins, cytokinin and ethylene or indirectly via the production of siderophores,

\footnotetext{
* Corresponding author

E-mail address: ajar@eternaluniversity.edu.in (AN Yadav)
} 
antagonistic substances, antibiotic, and synthesis of cell wall lysing enzymes like cellulases, gluconase, and glycosidase (Abo Nouh 2019; Urja and Meenu 2010).

Fungi play significant roles in agriculture, medicine and industry in different processes for sustainable development. In the medical field, fungi and their products are used for control disease in human and animals. They are involved in industrial processing make the 10 to 20 most beneficial products for human health, drug discovery research is ongoing and it is essential for daily human life. Mycorrhizal fungi are essential for the growth of plants. It is used as a food and also used to make fermentation products like alcoholic beverages, cheeses, bread, kefir, yogurt and various other food preparations (Abo Nahas 2019; Kotowski 2019; Rana et al. 2020b; Yadav 2019). The increasing demand for food to feed the growing population, organic and sustainable farming practice is required. The beneficial fungi have been used plant growth promotion and development for sustainable agriculture. The fungi are potentially useful for improving plant growth and health, nutrients availability, water uptake, stress tolerance and as well as biocontrol (Yadav et al. 2020a; Yadav et al. 2020b).

Now a day's fungi are used in many regions of the world as a biological pest control. Beneficial fungi play a significant role in numerous physiological processes, including minerals and water uptake, stomatal movements, photosynthesis and biosynthesis of compounds and in mitigation to environmental stresses like drought, heat, salinity, cold and heavy metals (AbdelSalam et al. 2017; Begum et al. 2019). The fungi could be applied as inoculants in the fields for crop production and protection. Mycofungicides and fungal biofertilizers were helped for agricultural uses to manage plant diseases as well as the environments defence its capability to improved crop production (Kour et al. 2020b; Suman et al. 2016b).

In recent years, there are different microbial fungicides have been developed like Ch. cupreum, Promote ${ }^{\circledR}$ developed from Trichoderma harzianum, $T$. viride, SoilGard® made from Gliocladium virens, Trichodex ${ }^{\circledR}$ work out from $T$. harzianum and Ketomium ${ }^{\circledR}$, constructed from Chaetomium globosum (Kaewchai 2009). The fungal biofertilizers with multifarious PGP attributes have been reported e.g. Trichoderma, mycorrhizal fungi (arbuscular mycorrhizae e.g. Glomus intraradices), ectomycorrhiza (Pisolithus tinctonus) and which form mutualistic associated with plants, whereas, Glomus sp. or Trichoderma sp. suppressed pathogens of fungal and species of Trichoderma (T. asperellum, T. atroviride, T. harzianum, $T$. virens, and $T$. viride) are commonly used in biocontrol and are known as biostimulants for 22 horticultural/agricultural crops. Fungal biofertilizers play a vital role in promoting plant growth, health and productivity as well as improving soil fertility (Frąc et al. 2018; Rana et al. 2019).

The present review, deals with the biodiversity of beneficial fungi from different habitats and their biotechnological applications in plant growth promotion and soil health.

\section{Biodiversity of fungal community}

In microbial ecology, diversity and distribution of microorganisms or microbes is one of the debated points and among them, the trending topic in this is fungi. Fungi, the decomposers, mutualisms, and pathogens are known to be extremely diverse. So far, total 712,000 fungal species both beneficial and pathogenic; have been known across the board (Schmit and Mueller 2007). These known fungal species were identified from the different regions like air, soil, plant-associated and various extreme environments such as deep oceans, hot springs, glaciers, deserts, mine and coastal region (saline areas) (Kour et al. 2019a; Sharma et al. 2019b; Rana et al. 2020a).

On review of different research on fungal diversity from diverse habitats, it is found that fungi reported are belonged to three different phyla (Figure 1) namely, Ascomycota, Basidomycota and Mucoromycotaand for more details check table (1) in supplementary materials.

The genera belong to phylum ascomycota are predominant. The abundance and relative distribution show that species of genera of genera Aspergillus are the most dominant (Figure 2).

\section{Plant associated fungal communities}

Plants, the recognized meta-organism, possess an association with distinct microbiome without which their life support function like nutrient acquisition, protection against environmental stress will not work. Within all microbes, fungi are also associated with the plants and in every plant, harbour has been symbiotically associated with particular fungi species, which fulfil the requirement of the host. In general, associated fungi are present in the three different plants regions (below and above ground) named as epiphytic or phyllosphere, endophytic and rhizosphere (Subrahmanyam et al. 2020; Tiwari et al. 2020; Yadav et al. 2018a).

Epiphytic or phyllosphere region of plant is comprised of aerial parts, especially leaves, and is a common niche for synergism between plant and fungi. The epiphytic region of the plants is exposed to the air and dust that result in the establishment of typical flora of fungi, which is aided by the waxes, cuticles and appendages. The fungi survive on the aerial parts of plants because they contain 
nutrients factors like sucrose, fructose, glucose and amino acids and in return fungi protect the plants from various air borne pathogens and helps in plant growth promotion. The fungi present in the phyllospheric region are also known as extremophiles as they survive in low/high temperature $\left(5-55^{\circ} \mathrm{C}\right)$ and harmful UV radiations (Yadav et al. 2017b). Huge amount of fungi like Alternaria alternate, Aspergillus fumigatus, A. niger, A. terries, Aureobasidium pullulans, Cladosporium cladosporioides, C. psoraleae, Curvularia lunata, C. oryzae, Drechslera rostrata, Epicoccum purpurascens, Humicola grisea, Mucor sp., Nigrospora oryzae, Oedocephallum sp., Rhizoctonia sp. (Kharwar et al. 2010), Trichoderma asperellum, T. atroviride, T. virens (Xia et al. 2011), Aureobasidium pullulans, Candida sp., Cryptococcus flavus, Hannaella coprosmaensis, Pseudozyma aphidis, Sporisorium reilianum, Ustilago esculenta (Sun et al. 2014), Cryptococcus flavus, Hannaella sinensis, Torulaspora globosa (Nutaratat et al. 2014),Aureobasidiumsp., $\quad$ Candida akabanensis,Dothideomycetes sp., Hanseniaspora uvarum, Meyerozyma caribbica, Saccharomyces cerevisiae, Barnettozyma californica, Cryptococcus laurentii, Pseudozyma aphidis, Pseudozyma prolifica, Pseudozyma rugulosa, Rhodosporidium paludigenum (Fu et al. 2016), Phyllosticta, Pseudocercospora (Yao et al. 2019), Torulaspora indica, Wickerhamomyces anomalus (Limtong et al. 2020) have been reported from this region of various plants.

Another very unique region of plants where fungi colonize is the endophytic region. This region of plant is referred to the interior parts like seed, stem and roots. The fungi residing in internal plant parts don't cause any pathogenic effects and lives in symbiotically (Bacon and White 2000), but during host senescence they may act as pathogens (Rodriguez et al. 2008). These types of fungi present inside the plant may be transmitted from the previous generation via seed, which is known as vertical transmission, or can be transmitted horizontally through the airborne spores (Hartley and Gange 2009), which produces certain cellulolytic enzymes, which is required for the hydrolyses of exothermal walls, such as endoglucanases and endopolygalacturonidases in order to penetrate inside the host plant (Suman et al. 2016a). Mostly fungi enter the plant by the mean of horizontal transmission (Aly et al. 2011). The number of fungi associated with various plants especially medicinal, have been identified like Alternaria alternate, Aspergillus niger, Stenella agalis (Kharwar et al. 2011), A. fumigatus, Colletotrichum dematium (Gond et al. 2012), Chaetomium globosum, Cladosporium cladosporioides, Daldinia fissa, Fusarium tricinctum, Gibberella moniliformis, G. avenacea, Petriella sp., Phomopsis sp., Valsa sordida, Schizophyllum commune, Sordaria humana(Qadri et al. 2013), Aspergillus peyronelii, Chaetomium sp. (Yadav et al. 2014), Fusarium tricinctum (Khan et al. 2015), Pestalotiopsis neglecta(Sharma et al. 2016), Leptosphaeria sp.(Yuan et al. 2017), Diaporthe phaseolorum (Hamzah et al. 2018), Penicillium daleae(Adhikari and Pandey 2019), Cladosporium cladosporioides(Yehia et al. 2020).

The third and very important region of plant is rhizosphere. Rhizosphere is the soil zone, which is influenced by the roots. In this region fungi or other microbes are attracted by the rhizodeposits known as exudates, which contains variety of compounds like sugars, organic acids, vitamins, hormones, amino acids, growth hormones, fatty acids and antimicrobial compounds. These compounds are used by the fungi as source of energy and derive maximum benefits and in reverse fungi promote plant growth directly by producing micro and macro-nutrients and indirectly by providing antagonist compounds (Yadav et al. 2017b). A number of microbes from this region is have been reported such as Penicillium sp., Trichoderma sp. (Murali et al. 2012), Aspergillus awamori(Jain et al. 2012b), A. fumigates, A. parasiticus, Chrysonilia sitophila (Gofar 2013), Aspergillus spp., Eupeniccilium sp., Isaria sp., Leptosphaerulina sp. (Mwajita et al. 2013), Dothideomycetes sp., Galactomyces candidum, Kazachstania jiainicus, Torulaspora sp. (Fu et al. 2016), A. terreus, andA. Luchuensis (Karunasinghe et al. 2020).

\section{Fungal communities from extreme habitats}

Fungi are ubiquitous, occupy a wide range of ecological niches and extreme habitats are one of that. Earth is surrounded by various types of ecosystem, and one of the unique habitats is extreme environments. The extreme environment included xerophilic, thermophilic (temperature $115^{\circ} \mathrm{C}$ ), psychrophilic (temperature -2$\left.20^{\circ} \mathrm{C}\right)$, halophilic $(10-30 \% \mathrm{NaCl})$, alkalophilic $(\mathrm{pH} 9)$ and acidophilic ( $\mathrm{pH}$ less than 4). These are the environment where normal life hardly exists, but it is a harbour of microbial diversity. Bacteria, archaea and fungi are the microbes that mostly survive in such harsh conditions. All these living organisms so as fungi that survive at such extreme conditions have special features that allow them to live in such habitats (Yadav 2017).

Temperature extremes are the conditions where fungi grow over a wide range. Temperature extreme can high temperature above $115^{\circ} \mathrm{C}$ and the fungi survive at such a high temperature are known as thermophilic fungi. 


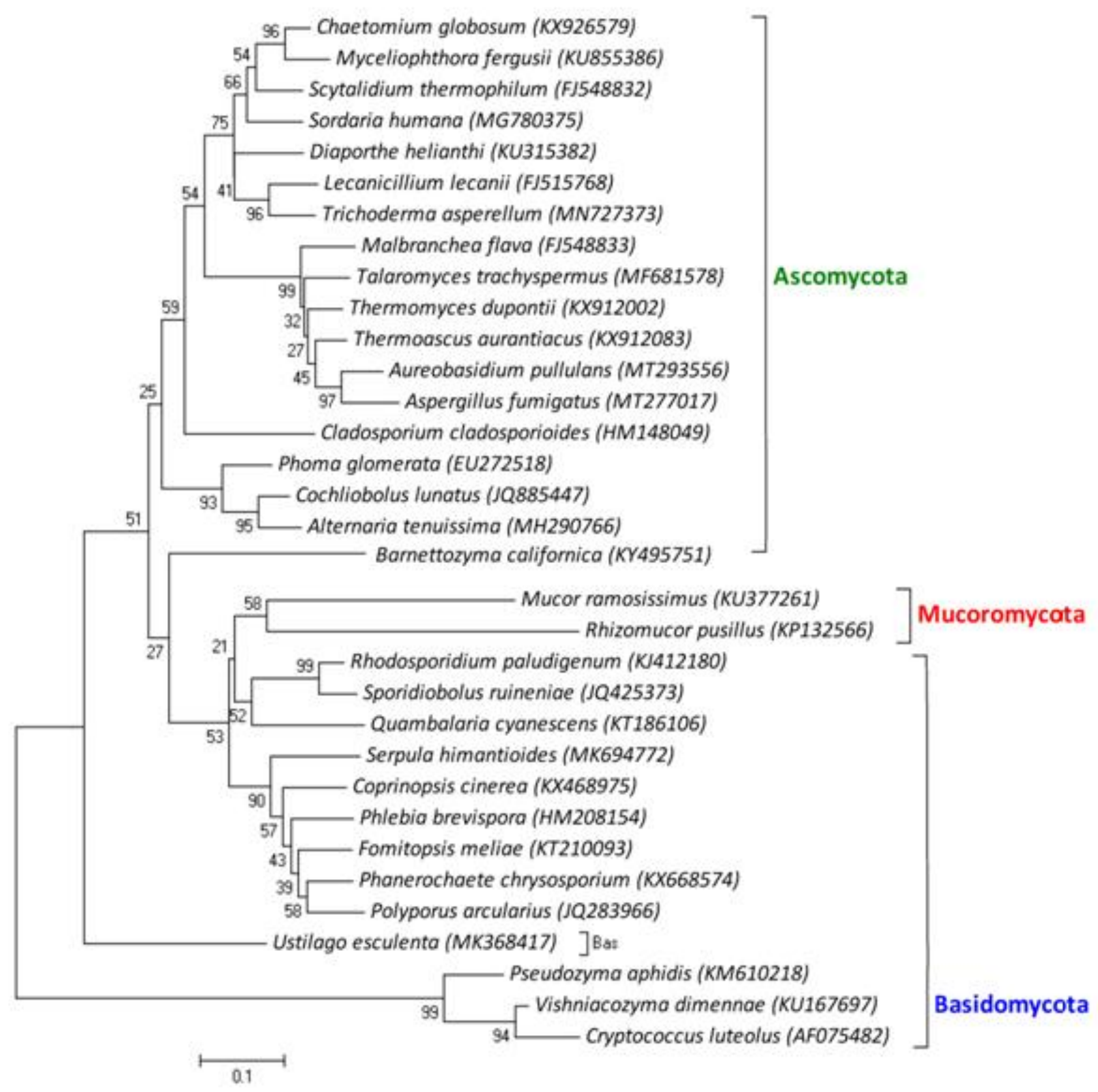

Fig1. Phylogenetic tree showing the relationship among fungi belonging to different phyla. 


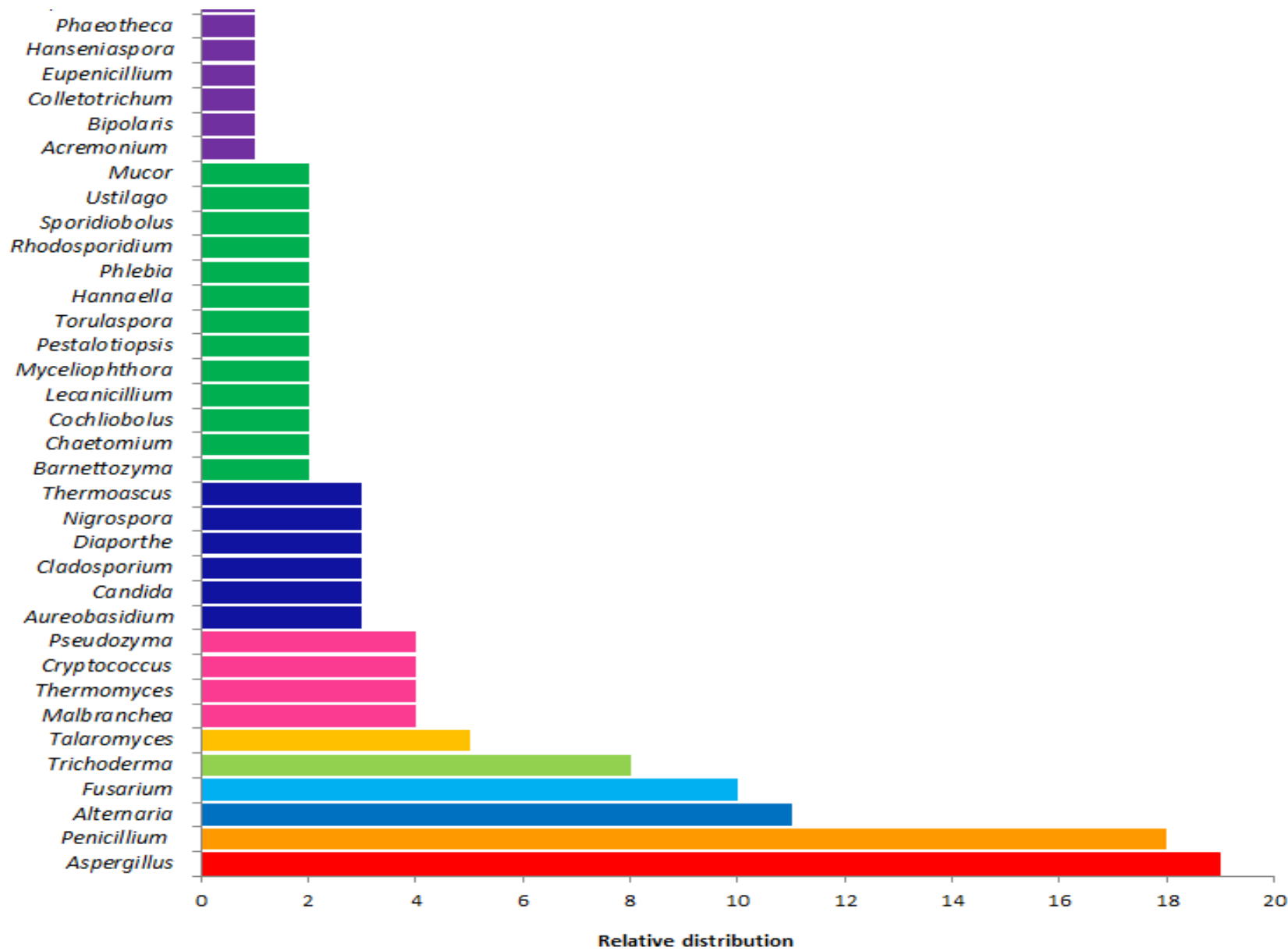

Fig 2. Relative distribution of pre-dominant genera of fungi reported from different habitats.

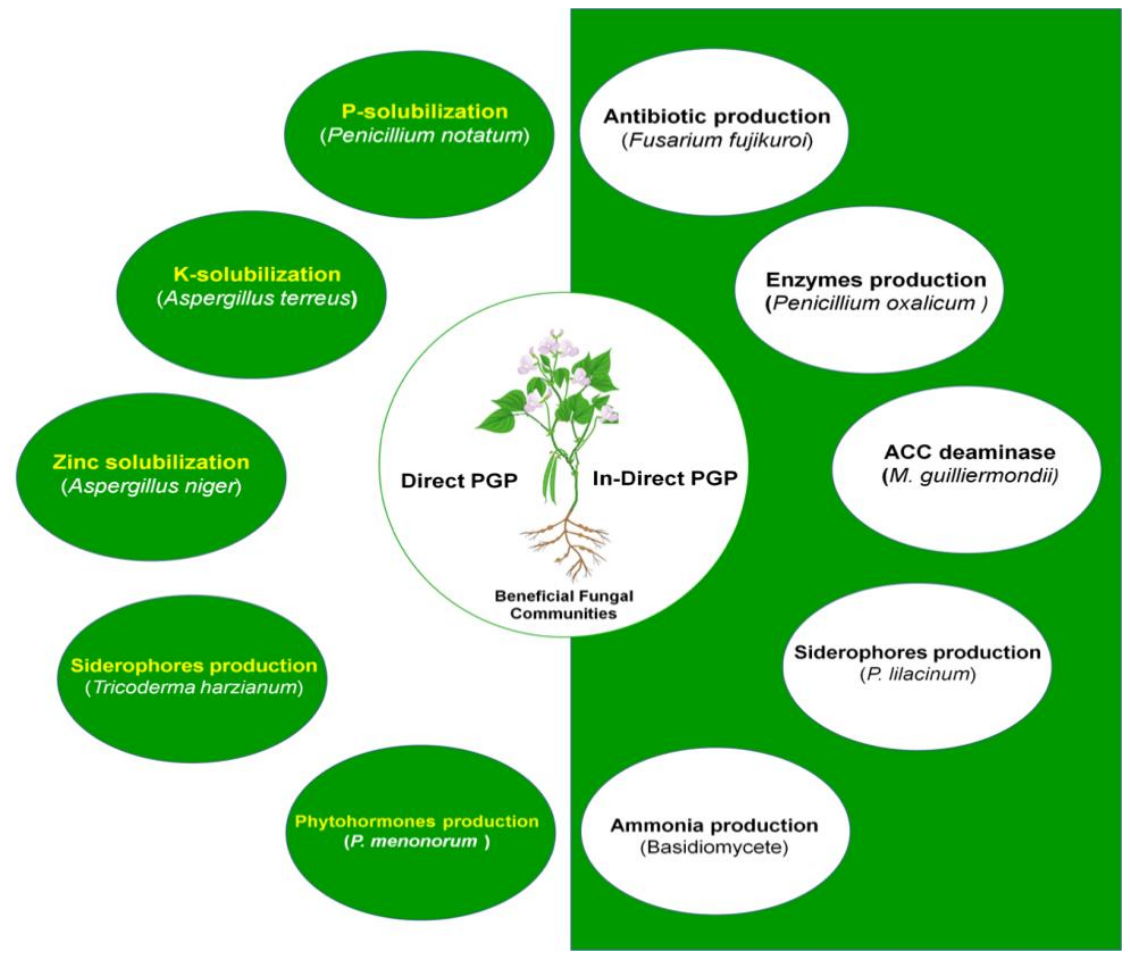

Fig 3. Various roles of beneficial fungal communities in plant growth promotion. 
Various fungal species have been isolated from such condition and being identified as Chaetomiumsp.,Coprinopsissp. Malbranchea flava, Myceliophthorasp., Scytalidium thermophilum, Talaromyces thermophilus, T.byssochlamydoides, Thermoascus aurantiacus(Pan et al. 2010), Aspergillus terreus,Malbranchea cinnamomea,Myceliophthora fergusii,Thermomyces lanuginosus (Maijala et al. 2012), Thermomyces lanuginosus, T. aurantiacus, Myriococcum thermophilum (Lee et al. 2014), Myceliophthora thermophila (de Cassia Pereira et al. 2015), Malbranchea cinnamomea, Melanocarpus albomyces (Ahirwar et al. 2017), Aspergillus fumigatus, Rhizomucor pusillus, Thermoascus crustaceus, Thermomyces dupontii, $T$. lanuginosus (Sandona et al. 2019), and Scytalidium thermophilum (Yang et al. 2020). Another temperature extreme is psychrophilic fungi that survive at the temperature range of $-2-20^{\circ} \mathrm{C}$. Fungi like Thelebolus sp. (Mukhopadhyay et al. 2014), Dothideomycetes sp.., Phoma herbarum, and Phomasp. (Moghaddam and Soltani 2014), Vishniacozyma globispora, V. dimennae (Tsuji et al. 2019).

pH extreme i.e. Alkalophilic and Acidophilic extreme habitats where $\mathrm{pH}$ can be high and cause alkalophilic conditions and low $\mathrm{pH}$ can be set the acidophilic conditions. Fungi like Emericellopsis alkalina, (Baranova et al. 2019), and Coprinopsis cinerea $(\mathrm{Xu}$ et al. 2019) were reported from alkalophilic conditions and Bispora sp.(Luo et al. 2009), Teratosphaeria acidotherma (Yamazaki et al. 2010), Purpureocillium lilacinum (Oggerin et al. 2013), Rhodotorula sp.(Su et al. 2019), and Aspergillus niger(Mukherjee et al. 2019) are the fungus known to be acidophilic. Halophilic condition is another harsh condition where salinity concentration of sodium chloride is high. In such condition fungi like Aureobasidium pullulans, Hortaea werneckii, Phaeotheca triangularis (Kogej et al. 2005; Turk et al. 2004), Debaryomyces sp. (Jiang et al. 2016), Aspergillus flavus (Beltagy et al. 2018), Gymnoascus halophilus, Wallemia sp. (Chamekh et al. 2019), Aspergillus sydowii and Aspergillus destruens (González-Abradelo et al. 2019).

\section{Mechanism of plant growth promotion}

The mechanism of plant growth-promoting fungi has been involved in both direct and indirect mechanism. Direct mechanism (phosphorus, potassium zinc) and plant growth regulators (auxins, cytokinin, ACC deaminase, gibberellins, ethylene, abscisic acid) as well as production of siderophores (Rastegari et al. 2020; Singh et al. 2020; Yadav et al. 2020e) (Fig.3) and for more details are added into table (2) in supplementary materials.

\section{Phosphorus solubilization}

Phosphorus is the second most important macronutrient after nitrogen for the plants. This macronutrient is a plant integral part like chemical structures and make up $0.2 \%$ of the plant's dry weight. Ironically, the largest reservoir of phosphorus is soil $(400-1200 \mathrm{mg} / \mathrm{kg}$ ) but in the insoluble form complexes with iron, calcium, aluminium which is not available to the plants (Bhattacharyya and Jha 2012). The soluble form of phosphorus in the soil very low for plants metabolism processes which is not sufficient and its deficiency may cause slower growth and reduced leaf biomass of the plant (Avdalović et al. 2015; Cakmak 2008). To fulfil the requirement several chemical fertilizers were being used which are not eco-friendly. Thus, fungi are considered as an alternative strategy because fungi are natural organism that provides soluble form of phosphorus without harming the environment.

The assimilation of phosphorus from the soil by the fungi is achieved by the production of various organic acids like tartaric acid, succinic acid, oxalic acid, malic acid, 2-ketogluconic acid, glyoxylic acid, gluconic acid, fumaric acid, citric acid and alpha-ketobutyric acid and enzyme phosphatase. All the release compounds solubilize the phosphorus and avail the soluble inorganic form that can be assimilated by the plants. A number of fungal species including $P$. bilaji, Penicillium spp. (Patil et al. 2012), P. oxalicum (Li et al. 2016a; Singh and Reddy 2011), Aspergillus niger, Penicillium notatum (Din et al. 2019; Malviya et al. 2011), Aspergillus awamori (Jain et al. 2012a), Penicillium bilaii (Ram et al. 2015), Trichosporon beigelii, Rhodotrula aurantiaca, Cryptococcus luteolus, Zygoascus hellenicus, $P$. purpurogenum var. rubrisclerotium, Neosartorya fisheri, and Candida montana (Gizaw et al. 2017), Talaromyces aurantiacus Aspergillus neoniger (Zhang et al. 2018a), and Trichoderma spp. (Bononi et al. 2020) have been reported for the solubilization of phosphorus.

\section{Potassium solubilization}

Potassium is the most abundant macronutrient they play a crucial role in plant growth and development. Those have the capacity to convert insoluble form which mineral potassium is available in to soil (Zeng et al. 2012). The soil was most important to the potassium solubilizing microorganism and they are necessary for potassium cycling(Diep and Hieu 2013). Potassium is the most important part of the microbial communities in soil especially in the rhizosphere and they play the most crucial role in plant growth by solubilization of potassium - bearing minerals. Mostly many formers have been used two types of fertilizers including nitrogen and phosphorus. They neglect potassium fertilizer because 
they are either unaware of $\mathrm{K}$ fertilizers value or the price of fertilizer is too high for poor formers to be out of control (Mohammadi and Sohrabi 2012). Therefore, potassium availability has been declining in soil, leading to more crop removal than fertilizer application. In this circumstance potassium solubilizing the microbe's position is gaining importance for sustainable crop production in modern agriculture. These fungus release potassium insoluble form which fungus is also beneficial for plant growth promotion by providing protection against plant pathogen and protecting them from stress condition (Archana et al. 2012; Gundala et al. 2013; Parmar and Sindhu 2013; Prajapati et al. 2013).A significant microbiome have been available in rhizospheric soil and improved plant growth by a number of mechanisms (Glick 2014; Nadeem et al. 2013). For the potassium solubilizination we can use large amount of microorganism like as Aspergillus spp., Agrobacterium tumefaciens, B. pumilus, B. subtilis, B. circulans, $B$. edaphicus, B. mucilaginosus, Flavobacterium spp. and Rhizobium spp. (Gundala et al. 2013; Keshavarz Zarjani et al. 2013; Maurya et al. 2015; Meena et al. 2014a; Meena et al. 2014b). Some scientist was estimated that bacterial species of Frateuria aurantia can be used as a biofertilizer to reduce approximately $50-60 \%$ of potash chemical fertilizer in the soil. This potash- solubilizing biofertilizer can be applied in crop production and yield combination with potassium solubilizing microbiome are Azospririllium, Azotobacter, Azospirillum, Acetobacter and Rhizobium (Bahadur et al. 2016). Chemical fertilizers have slowly begun their side-effects on humans and the environment; however, the potassium solubilizing microbes use as a biofertilizer will sustainably increase the available plant nutrients and crop production. It is most important to perform an effective research work to identify an elite microbial strain capable of quickly solubilizing large quantities of potassium minerals that can conserve our current resources and prevent environment contamination hazards caused by excessive in judicial use of chemical fertilizers. There are available two beneficial fungal communities of Arbuscular mycorrhizal fungi species $G$. intraradices and $G$. mosseaewe can be used as inoculants in the soil for the crop development.

Lian et al. (2002) was documented very similar findings and revealed that potassium solubilization was improved by thermophilic fungi of Aspergillus fumigates when we were inoculated on minerals of potassium solubilization microbes for plant growth and crop improving quantity. Another important and evolving factor concerning sustainable agriculture is the preparation of biofertilizer by using beneficial fungi (Priyadharsini and Muthukumar 2016; Raghavendra et al.
2016; Yadav and Sidhu 2016). Prajapati et al. (2012) was also reported two potassium solubilizing fungi like as Aspergillus terreus, A. niger, Glomas mosseae, $G$. intraradices and Penicillium sp. that was isolated from soil andobserved that Aspergillus niger and A. terreus could be solubilized to insoluble from in the soil. After that we were find out that potassium available in highest amount in the soil and shown large quantity in liquid medium by the using of two types of insoluble sources of potassium including potassium aluminium silicate and feldspar. Prajapati et al. (2013) and Sangeeth et al. (2012) also reported that potassium solubilizing fungi divided into two phylum such as Ascomycota and Glomeromycota as well as divided in to five genera Aspergillus, Cladosporium, Fusarium, Glomus and Penicillium it were essential plant growth promotion, and the crop protection(Verma et al. 2017a).In the whole world we are using a huge amount of chemical fertilizer in the sustainable agriculture they have been shown negative effect on the economy, environment and the human health. Generally, potassium solubilizing microbes had available in the market in the form of inoculums and biofertilizer to alleviate restriction of chemical fertilizer. It is an environmentally friendly solution to sustainable food production system in many countries across the globe.

\section{Zinc solubilization}

Zinc $(\mathrm{Zn})$ is known to be the $23^{\text {rd }}$ most abundant element on earth with five stable isotopes (Broadley et al. 2007). $\mathrm{Zn}$ plays an important role in many biochemical reactions as it is a structural constituent or a regulatory cofactor for different enzymes and proteins. The significant role of zinc finger as structural motif in regulation of transcription is also well known (Englbrecht et al. 2004). It is a vital nutrient required not only by plants but by humans and microbes. Humans require zinc in minute quantities throughout their lives for proper growth, development and physiological functions (Hambidge and Krebs 2007; Hussain et al. 2018). The deficiency of Zn has been ranked as the fourth main micronutrient deficiency in humans and is known to affect approximately $66 \%$ of the world's population (Zhang et al. 2012). The major reason behind deficiency is its inadequate intake (Cakmak 2010). Its deficiency in humans leads to various abnormalities in growth, immunity and brain development. Zn deficiency in fungi and bacteria causes impairment in formation of pigments including melanin, prodigiosin and subtilisin (Sindhu et al. 2019). Plants require zinc for regulation of cofactors for range of enzymes which are involved in maintenance of cellular membrane integrity, carbohydrate metabolism, regulation of auxin synthesis, pollen formation and 
protein synthesis (Alloway 2008). The deficiency leads to smaller leaves, stunted growth, shortened internodes and petioles, chlorosis, and spikelet sterility. Further, it negatively affects the equality of grains and plants become susceptible to infections and injuries (Cakmak 2010).

Deficiency of $\mathrm{Zn}$ in different members of community including animals and humans is manifestation of $\mathrm{Zn}$ deficiency in the crops that actually supply the community (Saravanan et al. 2011). The worldwide prevalence of $\mathrm{Zn}$ deficiency in crops is due to low solubility rather low $\mathrm{Zn}$ availability in soil (Iqbal et al. 2010). The soluble zinc sulphate is used as fertilizer to improve plant growth and productivity, but still there are constraints faced in absorbing zinc from the soil due to $\mathrm{Zn}$ fixation due to which it becomes unavailable for plant absorption. Zn-solubilizing microbes have great potential as compared to agrochemicals for improving the bioavailability of $\mathrm{Zn}$ (Yadav et al. 2020d). The use of microbes is gaining a greater attention in enhancing the crop productivity and restoration of soil fertility (Kumawat et al. 2019). Fungi have an immense potential of solubilizing $\mathrm{Zn}$ and tolerating high zinc level. Aspergillus niger was found to grow under $1000 \mathrm{mg} \mathrm{Zn}$, and this fungus is in fact used for quantification of $\mathrm{Zn}$ in soils containing low zinc (van Beelen and Fleuren-Kemilä 1997).

Fungi produce organic acids to increase the mobilization of the zinc present in the insoluble form to readily available form in the soil solution (Fomina et al. 2004; Sutjaritvorakul et al. 2017). The zinc solubilizing ability has been observed in ericoid mycorrhizae including Suillus bovines, Suillus luteus, Paxillus involutus, Oidiodendron maius, Hymenoscyphus ericae, and Beauveria caledonica (Fomina et al. 2005; Gadd 2007; Van Schöll et al. 2006). Fu et al. (2016) reported Aureobasidium pullulans, Barnettozyma californica, Dothideomycetes sp., and Torulaspora sp. with different plant growth promoting traits including zinc solubilization. Fungal strains like Trichoderma sp., Penicillium sp., Penicillium simplicissimum, Aspergillus niger, Abisidia spinosa, Abisidia glauca and Abisidia cylindrospora have been known to possess zinc solubilizing capability(Kour et al. 2020a; Kour et al. 2019a; Saravanan et al. 2011; Yadav et al. 2020c). The inoculation with $\mathrm{Zn}$ solubilizing fungi is a potential and eco-friendly technology to increase the bioavailability of native and applied zinc to the plants and an effective alternative to chemical fertilizers.

\section{Phytohormones productions}

Broad ranges of microbiome are found in the rhizosphere 28 they are able to produce several kinds of substances that are regulating plant growth and development and phytohormones are one of them. Phytohormones are the plant growth regulating substances that are produced by the plants itself for their proper functioning but in unfavourable conditions they are not able to secrete them. Fungi as well as other microbes have the ability to produce phytohormones such as auxins, abscisic acid, cytokinin, ethylene, gibberellins, jasmonic acid and salicylic acid that can be used by plants. These are play most important role in plant growth and development as well as in plant resistance/tolerance to abiotic stresses and in plant interactions with a variety of mutualistic fungi that can affect cell proliferation in the root architecture by over production of lateral roots and root hairs with a subsequent increase of nutrient and water uptake (Arora et al. 2013).

There are several reports producing phytohormones on plants microbes. The phytohormones producing microbes are inoculation to crop, enhancement of yield, plant growth promotion and development and the increasing soil fertility a for sustainable agriculture (Singh et al. 2017; Yadav et al. 2015a; Yadav et al. 2015b; Yadav et al. 2018b). Usually plant associated microbes develop growth hormones such as auxins and gibberellins. The most common indoleacetic acid (IAA) well known as auxin. When microbes are producing growth regulator hormones, they have been providing the host plant as well as including facilitating root expansion system and many kinds of several benefits. Which increases water and nutrient absorption and improve plant growth and developments that ability to synthesized these phytohormones is generally distributed surrounded by plant associated microorganism and indole acetic acid can be used to promote growth of plants or suppress weeds there are several types of microbial species when are capable of producing the auxins phytohormones IAA (Verma et al. 2017b).

Waqas et al. (2015) reported endophytic fungus of Paecilomyces formosus they play a vital role in heat stress and mitigation of phytohormones and secondary metabolites that were isolated from japonica rice. $\mathrm{Gu}$ et al. (2020) had been isolated fungal strain from barley seedling this fungus was named Penicillium citrinum also produce plant growth promoting secondary metabolites and phytohormones.

\section{Auxins}

Auxins are the most essential phytohormones they are indole derived hormones and it has been involved plant developmental process including elongation and differentiation, cell division, organ formation, promotes multiple growth and development (Sharma et al. 2019a). 
Auxin has also been influencing plant responses to biotic and abiotic stress condition (Peleg and Blumwald 2011). Auxins are synthesized from tryptophan, which is transformed by tryptophan 2-monoxygenase enzymes into indole- 3 acetamide. IAA has been synthesized chemically and identically. Ljung (2013) provided strong evidence in support of auxins mediated growth and regulation of development through alteration in pattern of gene expression. There have been many reports are available that depict various modulations in the synthesis, transport, metabolism and behaviour of auxins after plant exposure to stress, however, there are plenty of research reports that support the role of auxin in mediating and improving plant tolerance to abiotic stress (Kazan 2013). Auxins play a significant role in fostering heavy metal tolerance, whether directly or indirectly, as $\mathrm{Hu}$ et al. (2013) have been found that heavy metals shown adverse effect on auxin biosynthesis. There were also found in the fungi of Fusarium sp. And it has been reported to participate in the development of fungal auxin (Tsavkelova et al. 2012). However, several pathways have been available for the auxin syntheses were identified in fungi for example Fusarium sp. and Colletotrichum gloeosporioides auxin are synthesized from same precursors as in microbes indole- 3 acetamide but it can also be produce from indole-3 pyruvate, as observed in other fungal genera, for example, Ustilago and Rhizoctonia (Reineke et al. 2008). In addition, a tryptophan independent development of auxins has also been found but the corresponding pathways are still mot well defined.

Mehmood et al. (2018) havereported endophytic fungus Fusariun oxysporum they were isolated from maize roots. Endophytic fungi, however, encourage plant growth development and various secondary metabolites; they can help including ammonia and plant hormones, especially Indole acetic acid. (Gu et al. 2020) have been identified Penicillium commune of 112 variants when produce dibberellic acid like as GA3, GA4 and GA7 and other types of GA phytohormes. On the other hand, Babu et al. (2015)documented thatPenicillium menonorum were able to enhance plant growth, development and produce indole- acetic acid (IAA).

\section{Gibberellins}

The production of gibberellins is the most important for the root associated microbes and the production of auxins is commonly used to all plant associated microbes like as endophytic, rhizospheric and epiphytic. Gibberellic acid has been found to growth and development of the plants under various condition of abiotic stress (Ahmad 2010). Gibberellins regulate plant growth processes including seed germination stem extension, flowering and aging. Phytohormones and hormone- like compounds it can be ensure successful germination of seed or normal plant growth by controlling a symbiotic relationship between plant for example mycorrhizal fungi or nodule bacteria (Jaroszuk-Ściseł et al. 2014; Mefteh et al. 2017). Further most essential regulator gibberellins are necessary for plant production and development that had been play vital role in the development of lateral shoot growth, seed dormancy and the floral organs (Olszewski et al. 2002). There are several studies have also been documented we can improve germination and growth treated by the gibberellic acid under salt stress condition (Manjili et al. 2012; Tuna et al. 2008). According to Maggio et al. (2010) were treated tomato plants through the gibberellic acid under the saline condition where they have been observed that plant increased the crop growth and seed quantity. Gibberellic acid had been inducing most efficient absorption of iron within the plant system, leading to enhanced plant growth and the maintenance of plant metabolism under natural and stress condition (Iqbal and Ashraf 2013).

The endogenous application of GA resulted in alteration of plant osmotic stress and conservation of tissue water quality (Ahmad 2010). These results have been reported for wheat Manjili et al. (2012) and maize by Tuna et al. (2008). Furthermore, exogenous application of gibberellic acid mitigates the effects of salinity on germination and growth in Arabidopsis thaliana by mediating enhanced SA synthesis, which induces increased isochorismate synthase 1 activity (Alonso-Ramírez et al. 2009). Egamberdieva et al. (2017) reported that Arabidopsis improved salt tolerance gene and responsible for Fagus sylvatica they were producing gibberellins. Hasan (2002) recorded some fungi such as Rhizopus stolonifer, Pencillium funiculosum, $P$. cyclopium, P. corylophilum, Fusarium oxysporum, Aspergillus niger and A. flavus where all of the fungal species are capable to produce gibberellins but Fusarium oxysporum were found to producing both of phytohormones like as indole-acetic acid (IAA) and gibberellins (GA).

\section{Cytokinins}

Cytokinin have been involved in numerous fundamental process including plant growth promotion, plant morphogenesis, metabolism, nutrient assimilation, cell differentiation, cell proliferation and the translocation maintenance that are performing some important role in symbiotic interaction (Boivin et al. 2016). Cytokinins (CK) an important group of plant hormones they are involved in sustaining cellular proliferation and differentiation and in preventing senescence, leading to inhibition of premature senescence in the leaf (Schmülling 2002). Chemically, the normal cytokinins 
are derivatives of purine substituted by $\mathrm{N}^{6}$. These are found mainly in plant like as zeatin, 6 benzylaminopurine and kinetin as well as these are also considered to play a vital role in integrating diverse response to environmental stress (Dervinis et al. 2010). Cytokinin Reduced contributes to $\mathrm{ABA}$ induced stomatal closure, thereby reducing carbon absorption and assimilation under the stressful condition and regulation of cytokinin oxidase may also reduce carbon metabolism; research on this topic may be fruitful in improving plant growth and yield. Mohapatra et al. (2011) have been proved that cytokinin enhance the filling of grains. Exogenous application of cytokinin is currently being used to improved cytokinin internal concentration.

Heavy metals such as lead and zinc have also been reported to seriously crate the growth of chickpea seedling in large quantity, they are inhibiting by GA3 and $\mathrm{Z}$ in plants (Atici et al. 2005). In earlier research we found out that chickpea of kinetin has stimulating the plant hormones under the salt stress condition with an additional cytokinin increasing its antioxidant efficiency and kinetin extenuate cadmium in to eggplants (Singh and Prasad 2014). It has been shown to have a beneficial effect on the roots of Arbuscular mycorrhizal fungi and they are responsible for the tobacco phosphate transporter gene of NtPT4 and then decreases the cytokinin content in root as well as they have been caused root growth depression of the Arbuscular mycorrhizal fungi of colonized plants (Cosme et al. 2016). This indicated that cytokinin are essential plant growth defence trading regulators and highlights the important of the finely balanced responses plants and the environments.

\section{Ethylene}

Ethylene is crucial phytohormones that have a broad range of biological activities that can influence plants growth promotion and development there are a wide variety of ways including promotion root initiation, root elongation, fruit maturation and activating other phytohormones (Glick et al. 2007). Ethylene is controlling the flowering of flowers, plant growth adaptation, ripening of fruits, root formation, senescence, seed germination and seed dormancy under the biotic and abiotic stress condition (Abeles et al. 2012; Kende 1993). The gaseous hormone is synthesized as precursors ACC, which derived from methionine and ACC oxidase and ACC synthase is a central enzyme in this biosynthetic pathway (Xu et al. 2018). Iqbal et al. (2012)published that improved fresh biomass, grain yield, nodule dry weight, nitrogen content of grains, nodule number and straw yield of lentil grain have been reported as a result of reduced ethylene production through promoting plant growth with inoculation strains with Pseudomonas sp. contains ACC 30 deaminase, along with $R$. Leguminosa (Gupta et al. 2015).A gene that codes such as enzyme was not found in the genome of endophytic root-colonizing fungus Piriformospora indica. In the several studies Ethylene inhibits colonization of mycorrhizal fungi roots or rhizobacteria but there are also records of opposite effects (Khatabi and Schäfer 2012). Ansari et al. (2013) and Khatabi et al. (2012) synthesized Piriformospora indica strain of the fungus modulated through the ACC expression and ethylene were involving in ACC Arabidopsis.

\section{Abscisic Acid}

The abscisic acid phytohormones regulate many aspects of plant growth phytohormones and development of crop production including plant response various environmental stresses condition such as cold, desiccation and salinity (Finkelstein 2013). Abscisic acid is a typical stress hormone that is involved in so many osmotic reactions like as stress on salt and drought. Abscisic acid relevance to beneficial synergistic relationship has recently become an important area under study. Generally abscisic acid promotes Arbuscular mycorrhizal fungi symbiosis although the effect of the hormones is highly dependent on the developmental stage of the conditions of interaction and stress. López-Ráez (2016) and PeskanBerghöfer et al. (2015) showed that treatment of Arabidopsis seedling with exogenous ABA or ABA analog pyrabactim increased the efficiency of the fungal colonization without harm of plant fitness. Like other phytohormones ABA is play an important role in plant by enhancing responses and adaptation to stress. They are a naturally occurring sesquiterpenoid which is a group of main growth controlling phytohormones. The role of $\mathrm{ABA}$ in combining signalling with subsequent control of downstream responses during stress exposure has been confirmed by several studies (Wilkinson et al. 2012). The expression of stress-responsive gene had controlled by ABA - induced and mediated signalling under abiotic stress contributes to better elicitation of tolerance response (Sah et al. 2016). Additionally, under of drought stress condition, ABA was documented to regulate root growth and water content (Cutler et al. 2010).

\section{Antibiotic productions}

The term antibiotics covers wide range of chemical substances produced naturally, semi-synthetically and synthetically and used to inhibit (bacteriostatic) growth kill (bactericidal) bacteria (Gillings 2013; Martínez 2012; Milić et al. 2013). They are classifying as narrow or broad-spectrum antibiotics based on their effects as either bacteriostatic or bactericidal and on their series of 
effectiveness. In additional, the group of drug that are more broadly used in global level of the agriculture, that are increasing technical concern with regards to their possible adverse effects and risk reduction measures steps including the aminoglycosides, $\beta$-lactams, lincosamides, macrolides, pleuromutilins, sulphonamides and tetracyclines (Baynes et al. 2016; De Briyne et al. 2014; Finley et al. 2013).Fungi are very important to the soil ecosystem and play an incredible role in the everyday life of humans being as well as biofertilizers for the field of agriculture, bioremediation, natural regeneration and also used in food industries (Karthikeyan et al. 2014; Yadav and Yadav 2018). Additionally, fungi are also a significant source of secondary metabolites and ecologically, soil was considered abundant sources of antibiotic- producing microbes in the microbially reach environments due to strong competitions for nutrients and territory.

Over the 60 years ago the screening of the antibiotics was started with the organism of the soils and secondary metabolites contain high quantity from fungi were obtained from the soil for example production of secondary metabolites, antimicrobial agents, is one of the most significant uses of fungi that can potentially be useful for medical therapy (Al-Daamy et al. 2018; Farjana et al. 2014). These secondary metabolites are referred to as small organic molecules formed by organisms that are not required for their growth, development and also the reproduction; rather than they play an essential role against other living organisms in antagonism, competition and self-defence mechanism to enable the organism to occupy the niche and use the food. Fungi produced various antibiotics that exhibit antifungal and antibacterial activity, correspondingly that are broadly used as drugs worldwide, especially penicillin, cephalosporin, and fluidic acid (Al-Enazi et al. 2018). Additionally, endophytes of vascular plants have been the most widely explored ecological group in recent years (Karwehl and Stadler 2016). Novel antibacterial, anticancer, antifungal, anti-inflammatory, ant-malarial and antiviral substances have been reported to be produced by fungal endophytes (Higginbotham et al. 2013; Supaphon et al. 2018).

Antibiotics are commonly used products from agriculture and their functional amount is at least as high amount uses in humans. The calculation approximately that the extract amount of antibiotics used in global agriculture varies significantly as well as 50,000 tons per annum and theses antibiotics are mostly used in crop processing, animal husbandry and also used in aquaculture containing a similar chemical structure amid

antibiotics used for human therapy. Antibiotics are used in a few parts of the worlds for the larger quantity in the animal husbandry apart used via humans. In crop production antibiotics uses is comparatively inferior to use in livestock. Specifically, the outspread use of antibiotics, they are free for all haphazard uses in agriculture, have threatened by the emergence of important pathogenic high level of antibiotics and /or antimicrobial resistance. Some human pathogens have evolved resistance stain (MRSA and VRE) to the commercial antibiotics that are difficult to treat some lifethreatening diseases that were previously thought to be safe. Some plants diseases are causing microbes have also developed resistance strain to important antibiotics like streptomycin and oxytetracycline (Sarkar et al. 2018).

In this study, Gajera et al. (2016), reported Trichoderma viride showing antioxidant effect against Aspergillus niger pathogens of collar rot in groundnut. In Another study carried by Al-Daamy et al. (2018) have screened antimicrobial activity against and using to disc technique Streptococcus agalactiae, Staphylococcus sp., Pseudomonas sp., Klebsiella sp., Enterobacter sp., Bacillus sp., and the filtrates of Trichoderma sp., Penicillium notatum, Cladosporium sp., Bacillomyces sp., Aspergillus ochraceus, A. niger, A. flavus. In another investigation bacillus $\mathrm{sp}$. is the most sensitive to all fungal species. In additional Awad et al. (2018) identified aTrichoderma viridae showing anticancer, antioxidant as well as antimicrobial activity these was isolated from rhizospheric soil of cucumber. In this study Tricoderma viride suppress of the mycelia growth of Sclerotium rolfsii, Fusarium solani and also Rhizoctonia solani. Additionally, fungal mycelia exhibited alcoholic extract of a potent antibacterial activity against Bacillus subtilis, E. coli, and Pseudomonas fluorescens as well these also exhibiting considerable antifungal activity against Candida albicans, Pythium ultimum, Fusarium oxysporum, Rhizoctonia solani and Fusarium solani. Furthermore Ribeiro et al. (2018) detected Diaporthe sp. and Curvularia sp. inhibited against pathogenic gramnegative with positive bacteria like Staphylococcus epidermidis, Pseudomonas aeruginosa, Staphylococcus aureus and E. coli. Iswarya and Ramesh (2019) reported Penicillium daleae EF4 showing antimicrobial activity against Staphylococcus aureus, Pseudomonas aeruginosa isolated from Seaweed Enteromorpha flexuosa Linn. Another reported fungi Aspergillus niger, Fusarium fujikuroi and Geotrichum condidum have antimicrobial activity against Staphylococcus aureus, Salmonella sp. and Streptococcus pyogenes isolated from pediatric patients (Afolami et al. 2020).

\section{ACC (1-aminocyclopropane-1-carboxylate) deaminase activity}


In the soil environment, a healthy plant faces both abiotic and biotic stress conditions that negatively affect the growth and development of the plants. The stress conditions include drought, flooding, heavy metal, salinity, low and high temperature (Nadeem et al. 2012) and the presence of pathogens. These stress conditions lead to certain physiological disorders in plants such as the nutritional and hormonal imbalance and increased production of ethylene (Sairam and Tyagi 2004). Ethylene is required by the plants for their normal growth and development and is also involved in the response of plants to various stresses (Glick 2014). The growth of the plant tissues, including flowers, fruits, leaves, roots, and stems, are affected by ethylene. The interaction of plants with mycorrhizal fungi involves ethylene (Gamalero et al. 2008). But the higher concentration of ethylene inhibits the elongation of the roots and nodulation in legumes, leads to defoliation, epinasty, leaf abscission, and leaf senescence (Yadav et al. 2020e).

Certain fungal genera help the plants to survive and grow under biotic and abiotic stress conditions by decreasing the inhibitory levels of ethylene with the help of 1-aminocyclopropane-1-carboxylate deaminase (ACCd) enzyme. ACCd is a pyridoxal phosphatedependent enzyme that breaks down the immediate precursor of ethylene i.e., ACC into ammonia and $\alpha$ ketobutyrate (Singh et al. 2015) thereby reducing the harmful effects of ethylene. Trichoderma asperellum was evaluated for ACCd enzyme and fungal cultures grown with ACC as the sole nitrogen source showed high ACCd enzymatic activity (Viterbo et al. 2010). The study of Aban et al. (2017) showed ACCd activity in symbiotic fungi Meyerozyma guilliermondii, Trichoderma simmonsii, Trichoderma yunnanense and unidentified strains belonging to Mucoromycotina. ACCd producing fungi can help their host plants to survive and grow under the environmental stress conditions.

\section{Hydrolytic enzymes production}

Presently, enzymes are receiving considerable interest because of their applications in different fields including industries, like food, detergent, textiles, leather, pulp and paper and agriculture field. Fungi are known to produce certain type of enzymes like cellulose, laccase, pectinases and cellulase, which has been explained further.

\section{Xylanases}

Xylanase, an endo- $\beta-1,4-x y l a n a s e$ is the hydrolytic enzyme that has necrotizing and enzymaticactivity that can trigger the plant immunity. This enzyme is glycoside hydrolase that catalyse the hydrolysis of $\beta-1,4$-xylan which is a structural polysaccharide abundantly presenting the primary cell wall of monocot plants. This enzyme also has an antagonist activity against various pathogens that inhibits plant growth (Tundo et al. 2020). Xylanase can be produced by the various fungal species like Aspergillus niger (Park et al. 2002), A. foetidus (Shah and Madamwar 2005), Penicillium oxalicum (Li et al. 2007), A. tubingensis, A. Terreus (Bakri et al. 2010), A. fumigatus (Ang et al. 2013), Trichoderma viride (Irfan et al. 2014), and Trichoderma citrinoviride (Lee et al. 2020).

\section{Laccase}

The enzyme laccases are the multi-copper monomeric glycoproteins which are widely distributed and have the potential to oxidize a broad spectrum of compounds of phenolic and non-phenolic. This enzyme is being used in industries like cosmetics, food, paper and pulp, pharmaceutical and textile. This enzyme is also used for the degradation of agricultural waste. Bacteria and fungi are known to produce this enzyme. Fungi are known to be the major producers and more than 60 fungal species belonging to Ascomycota, Basidiomycota, and Zygomycotawere reported (Kour et al. 2019b).

\section{Pectinases}

Pectinase refers to the group of enzymes that have an ability to catalyse pectin and pectic material by various pathways like de-esterification, hydrolysis and transelimination. This enzyme is widely used in the production of fruit juice and alcoholic beverages, poultry feed, textile product and paper, treatment of wastewater, extraction of vegetable oil, fermentation of tea and coffee (Tepe and Dursun 2014). This enzyme has also been reported for showing antagonist activity against pathogens. Fungi like Thermomucor indicae seudaticae (Martin et al. 2010), Penicillium chrysogenum (Banu et al. 2010), A. japonicus and $P$. glandicola (Bezerra et al. 2012), A. niger (Ahmed et al. 2016; El Enshasy et al. 2018; Geetha et al. 2012; Ortiz et al. 2017; Sandri et al. 2013; Wang et al. 2019) and A. tamari have been reported for producing pectinase enzyme(Amande et al. 2020).

\section{Cellulase}

Cellulase, a homopolymers of repeated units of cellobiose, which have the $\beta 1,4$-glycosidic linkages that makes structural organization highly ordered and tightly packed is third largest enzyme that have been used worldwide for animal feed additives, cotton processing, detergent production, juice extraction and paper recycling. Nowadays, cellulase enzyme are known to have an agricultural application like plant growth promotion by the killing the pathogens. Cellulase kill 
pathogens by hydrolysing the cellulose- the major component of the cell wall of certain pathogens- by cleaving the internal bond of glycan chain and provide reducing or nonreducing ends of cellooligosaccharides for cellobiohydrolases $(\mathrm{CBH}$; or exoglucanase, 1,4- $\beta$-Dglucan-cellobiohydrolase, EC 3.2.1.91) to attack. After that $\mathrm{CBH}$ hydrolyses chain ends and yieldcellobiose as the major product. At last, this cellobiose is hydrolysed by $\beta$-glucosidase into glucose and also releases glucose from the nonreducing ends of soluble cellooligosaccharides (Phitsuwan et al. 2013). Some fungi like Fusarium chlamydosporum (Qin et al. 2010), Acremonium cellulolyticus (Kanna et al. 2011), Fomitopsis sp. (Deswal et al. 2011), Phanerochaete chrysosporium (Govumoni et al. 2015), Trichoderma reesei (Bischof et al. 2016; He et al. 2019; Linke et al. 2015; Subramanian et al. 2017), Myceliophthora thermophila (Li et al. 2020), and Penicillium sp. (SilvaMendoza et al. 2020) have been reported for producing this enzyme.

\section{Siderophores production}

Iron is the fourth most abundant element in ground rock. Iron is the most essential micronutrients for the development of the plant and the plants involved in the most critical biological cycling, including chlorophyll biosynthesis, respiration and photosynthesis (Dixon and Kahn 2004; Kobayashi and Nishizawa 2012). Siderophores are produced a low molecular weight of compounds they can be utilized through the microorganism like bacteria and fungi as an iron (Fe) chelating agents. These compounds produce numerous kinds of microbes due to low iron solubility; they were responsible for iron deficiency and normally available in natural alkaline high pH soil(Sharma and Johri 2003). High ferrous ion $\left(\mathrm{Fe}^{2+}\right)$ concentration have been decreasing $\left(\mathrm{Fe}^{3+}\right)$ ions may lead to iron toxicity in anaerobic condition and the acidic soils, such as flooded soils, due to excessive iron absorption(Stein et al. 2009).

Which are responsible for the solubilization and transportation of this product into bacterial cells. Some bacteria produce siderophores of the hydroxamate form and others bacteria have been produce catecholate form (Ahmad et al. 2008). Microbes have evolved aggressively Fe taking strategies. The nutritional weakness of iron can be overcome by bacteria using chelator agents called siderophore. The siderophore producing microbes are able to bind and transport the iron- siderophore complex in a state of iron limitation through the expression of different proteins. The development of microbes' siderophore is beneficial to plants as it can inhibit the growth of plant pathogen. Siderophores have been involved in direct and indirect plant growth enhancement by microbial plant growth (Yadav et al. 2017b). While studying the typification of siderophores, it was found that Trichoderma harzianum reported with maxium hydroxymate and corboxylate production while $T$. asperellum, T. longibrachiatum, T. Virtue reported with lower hydroxymate and carboxylated content, as confirmed by the strength of colour.

Ghosh et al. (2017) was identified three fungal species they were showing antagonistic activity against Trichoderma asperellum, T. harzianum, T. viride. Usha and Padmavathi (2013) was documented two fungal species Aspergillus flavus and A. niger that have been secreting less iron compound with secondary metabolites siderophore. In another study we were found plant growth-promoting fungi like as Trichoderma Asperella, Pochonia chlamydosporia, Purpureocillium lilacinum, Metarhizium anisopliae, Beauveria bassiana.Farias et al. (2018) were applied to crop of corn, sugarcane, soybean and tomato they were grown under two treatment conditions such as control without inoculation and inoculation with the fungal consortium. We have been identified and characterized siderophore-producing fungi that can be used as biofertilizers and biocontrol.

\section{Functional annotation for sustainable agriculture}

\section{Fungi as plant growth promoters}

In agriculture, fungi are gained significant popularity as a plant growth promoter. Mostly, various bacterial species have been studied and researched for enhancement of plants, but fungi are considered far superior. Fungi possess several characteristics features that bacteria do not pose like better ability over bacteria to tolerate harsh acidic conditions, mobilize nutrients like phosphorus, and produce phytohormones including IAA, gibberellins and siderophores (Kumar et al. 2018). The main mechanisms by which fungi enhance the growth of plants are nutrients acquisition and providing growth hormones.

Plants require various types of micro and macronutrients for their growth, which they absorb from the soil. But nowadays, available soil nutrients have been depleted due to conventional agriculture (over exploitation of chemical-based products), so, plants are not able to uptake the necessary requirements. Several types of chemical products for plants are available and being used by the farmers that have very deleterious effects on the environment as well as humans. So, fungi are the better alternative for nutrients acquisition. Fungi undergo mechanisms like solubilization that make available soluble forms of nutrients like phosphorus, potassium, zinc, and magnesium from the insoluble forms. Fungi also have an ability to produce low molecular weight siderophores that can use for the 
sequestration of iron (Kour et al. 2019b). The number of fungi has been reported for the acquisition of different nutrients like Azospririllium, Azotobacter, Azospirillum, Acetobacter and Rhizobium (Bahadur et al. 2016) reported for the potassium solubilization, Aureobasidium pullulans, Barnettozyma californica, Dothideomycetes sp., and Torulaspora sp. Was reported for the zinc solubilization (Fu et al. 2016).

Another potential of fungi that helps in the plant growth promotion is the biostimulation. Fungi produce of various phytohormones like auxin, cytokinin, gibberellins, abscisic acid and ethylene. These phytohormones are produces by plants also, but sometimes when conditions are not favourable production of phytohormones reduces that affects the plant growth. So, fungi have been reported for the production of phytohormones that enhances plant growth. Species like Fusarium sp., Colletotrichum gloeosporioides (Reineke et al. 2008), Penicillium menonorum (Babu et al. 2015) have been reported for auxin production, whereas, Fagus sylvatica(Egamberdieva et al. 2017), Rhizopus stolonifer, Pencillium funiculosum, P. cyclopium, P. corylophilum, Fusarium oxysporum, Aspergillus niger and A. flavus. Hasan (2002) reported for the gibberellins production. Piriformospora indica was reported for the production of ethylene (Ansari et al. 2013; Khatabi et al. 2012).

\section{Fungi as biological control agents}

Pathogens affecting plant health are a major and chronic threat to food production and ecosystem stability worldwide (Compant et al. 2005). It has been estimated that about $10-16 \%$ of global food production is reduced due to field and post-harvest plant diseases (Lo Presti et al. 2015; Strange and Scott 2005). Since agriculture is the largest economic sector in the world so to ensure high yield pesticides including bactericides, fungicides, herbicides and insecticides are used. It has been estimated that more than two billion tons of pesticides are used every year all over the world to eliminate undesirable crop pests. But pesticides leave undesirable effects in the environment including the contamination of soil, groundwater and water bodies which then affect human and animal health due to their carcinogenic potential, recalcitrance, and toxicity (Baron et al. 2019).

Microbial diversification is one of the most important components of world biological diversity. Recent technologies utilized to study microbial diversity have found that a large proportion of microbes still remain undiscovered and further many of their ecological roles still remain unknown (Kumawat et al. 2019). Diverse groups of microbes have been known to play an important role in the agricultural sector such as biofertilizers enhancing the growth and productivity, maintaining soil health and fertility as well as biocontrol agents where they protect the plants against pathogens. Biocontrol is the use of beneficial organisms, their genes, and/or products, to lessen the negative impact of plant pathogens and promote positive responses by the plant (Vinale et al. 2008). Biological control of pests has been recognized as an alternative to the use of harmful pesticides. Though different groups of microbes have been reported with potential as biocontrol agents but fungi are most studied and applied (Schrank and Vainstein 2010).

The use of fungi as biocontrol agents is greatly beneficial due to their metabolic diversity and efficiency that enhances the chances of finding the apt isolates for biocontrol and their relative environmental safety, as they are primarily decomposers (Thomas and Read 2007). Fungi belonging to genera Aspergillus, Fusarium, Gliocladium, Petriella and Trichoderma are known to be important biocontrol agents (De Silva et al. 2019). The biocontrol activity of Verticillium leptobactrum against wilt disease induced by Fusarium oxysporumF.lycopersici has been demonstrated by HajjiHedfi et al. (2018).

Further many fungal biocontrol agents are also available as commercial products such as Verticillium lecanii, Trichoderma polysporum, Trichoderma gamsii, Trichoderma asperellum, Purpureocilium lilacinum, Phlebiopsis gigantean, Paecilomyces lilacinus, Metarhizium anisopliae, Gliocladium catenulatum, Coniothyrium minitans, Candida oleophila, Beauveria bassiana, Aureobasidium pullulans and Ampelomyces quisqualis (Larran et al. 2016; Tranier et al. 2014). The use of fungi as biocontrol agents is a safe and ecofriendly strategy towards sustainable agriculture. Furthermore, hidden possibilities or uses of fungi could be explored to enhance agricultural productivity, nanoagriculture, and metabolite production (Singh et al. 2019).

\section{Conclusion}

The scientific community has been conscious for the past two and a half decades fungi play an important role in agriculture, medicine, ecology, biotechnology, and industries. They are also alternative approaches to exiting the enzymatic process these can be utilized in fermentation industries. Fungi are also having a multifarious role in plant growth promoting and make to environmentally safe. So, these fungi could utilize as biopesticides/biofertilizers in the field under stress conditions for plant growth and make to healthy. As a result, fungi are becoming more attractive in the situation of global must as novel sources of food, enzyme and antibiotics as well as secondary metabolites. In future work, fungi are needed still in many areas to be explored, including new innovation and crops. In the modern 
techniques of molecular biology, occupied proteomes, transcriptomes and metagenomes, can help to characterized and identified to find novel products for industrial growth. For future fungi research is hopeful, as a demand for pharmaceutical goods and agricultural products required.

Conflict of interest: The authors have no conflicts of interest to declare. All co-authors have seen and agree with the

contents of the manuscript.

Contribution: Rubee Devi, Tanvir Kaur, and Divjot Kour contributed equally to this review

\section{References}

Aban JL, Barcelo RC, Oda EE, Reyes GA, Balangcod TD, Gutierrez RM et al. (2017) Auxin production, phosphate solubilisation and ACC deaminase activity of root symbiotic fungi (RSF) from Drynaria quercifolia L. Bull Environ Pharmacol Life Sci 6: 2631

Abdel-Salam E, Abdulrahman A, Mohamed A (2017) Inoculation with arbuscular mycorrhizal fungi alleviates harmful effects of drought stress on damask rose. Saudi J Biol Sci 25: 1772-1780

Abeles FB, Morgan PW, Saltveit Jr ME (2012) Ethylene in plant biology. Academic press,

Abo Nahas HH (2019) Endophytic fungi: A gold mine of antioxidants. Microb Biosyst 4:58-79

Abo Nouh FA (2019) Endophytic fungi for sustainable agriculture. Microb Biosyst 4:31-44

Aboobaker Z, Viljoen A, Chen W, Crous P, Maharaj V, van Vuuren S (2019) Endophytic fungi isolated from Pelargonium sidoides DC: Antimicrobial interaction and isolation of a bioactive compound. S Afr J Bot 122:535-542

Adhikari P, Pandey A (2018) Phosphate solubilization potential of endophytic fungi isolated from Taxus wallichiana Zucc. roots. Rhizosphere 9:2-9

Adhikari P, Pandey A (2019) Phosphate solubilization potential of endophytic fungi isolated from Taxus wallichiana Zucc. roots. Rhizosphere 9:2-9

Afolami O, Arogunjo A, Oladunmoye M, Owoyemi O, Aribisala J, Ajayi-Moses O et al. (2020) Lactobacillus sp and some fungi from termite nests on kolanut trees had mild antagonistic effects against pathogens isolated from paediatric patients. Afr J Clin Expe Microbiol 21:140-148

Ahirwar S, Soni H, Prajapati BP, Kango N (2017) Isolation and screening of thermophilic and thermotolerant fungi for production of hemicellulases from heated environments. Mycology 8:125-134

Ahmad F, Ahmad I, Khan M (2008) Screening of freeliving rhizospheric bacteria for their multiple plant growth promoting activities. Microbiol Res 163:173181.

Ahmad P (2010) Growth and antioxidant responses in
mustard(Brassica juncea L.) plants subjected to combined effect of gibberellic acid and salinity. Arch Agron Soil Sci 56:575-588

Ahmed I, Zia MA, Hussain MA, Akram Z, Naveed MT, Nowrouzi A (2016) Bioprocessing of citrus waste peel for induced pectinase production by Aspergillus niger; its purification and characterization. J Radiat Res Appl Sci 9:148-154

Al-Daamy A, Ahmed A, Mohammad G (2018) Antimicrobial zagents' production by fungi isolates from the whisperers. Sci J Med Res 2:104-107

Al-Enazi NM, Awaad AS, Al-Othman MR, Al-Anazi NK, Alqasoumi SI (2018) Isolation, identification and anti-candidal activity of filamentous fungi from Saudi Arabia soil. S Pharm J 26:253-257

Alloway B (2008) Zinc in soils and crop nutrition. Published by IZA and IFA. Brussels, Belgium and Paris, France 139

Alonso-Ramírez A, Rodríguez D, Reyes D, Jiménez JA, Nicolás G, López-Climent M et al. (2009) Evidence for a role of gibberellins in salicylic acid-modulated early plant responses to abiotic stress in Arabidopsis seeds. Plant Physiol 150:1335-1344

Aly AH, Debbab A, Proksch P (2011) Fungal endophytes: unique plant inhabitants with great promises. Appl Microbiol Biotechnol 90:1829-1845

Amande T, Adebayo-Tayo B, Ndubuisi-Nnaji U, Ado B (2020) Production and partial characterization of pectinases from mango peels by Aspergillus tamarii. J Microbiol Biotechnol Food Sci 9:59-62

Ang S, Shaza E, Adibah Y, Suraini A, Madihah M (2013) Production of cellulases and xylanase by Aspergillus fumigatus SK1 using untreated oil palm trunk through solid state fermentation. Proc Biochem 48:1293-1302

Ansari MW, Trivedi DK, Sahoo RK, Gill SS, Tuteja N (2013) A critical review on fungi mediated plant responses with special emphasis to Piriformospora indica on improved production and protection of crops. Plant Physiol Biochem 70:403-410

Archana D, Nandish M, Savalagi V, Alagawadi A (2012) Screening of potassium solubilizing bacteria (KSB) for plant growth promotionalactivity. Bioinfolet-A 
Quarterly J. Life Sci. 9: 627-630.

Arora NK, Tewari S, Singh R (2013) Multifaceted plantassociated microbes and their mechanisms diminish the concept of direct and indirect PGPRs. In Arora NK (ed) Plant microbe symbiosis: Fundamentals and advances. Springer, India, New Delhi, pp 411-449. doi:10.1007/978-81-322-1287-4_16

Atici Ö, Ağar G, Battal P (2005) Changes in phytohormone contents in chickpea seeds germinating under lead or zinc stress. Biol. Plant. 49:215-222.

Avdalović J, Beškoski V, Gojgić-Cvijović G, Mattinen M-L, Stojanović M, Zildžović S et al. (2015) Microbial solubilization of phosphorus from phosphate rock by iron-oxidizing Acidithiobacillus sp. B2. Miner. Eng. 72: 17-22.

Awad NE, Kassem HA, Hamed MA, El-Feky AM, Elnaggar MA, Mahmoud K et al. (2018) Isolation and characterization of the bioactive metabolites from the soil derived fungus Trichoderma viride. Mycology 9:70-80

Babu AG, Kim SW, Yadav DR, Hyum U, Adhikari M, Lee YS (2015) Penicillium menonorum: a novel fungus to promote growth and nutrient management in cucumber plants. Mycobiology 43:49-56

Bacon CW, White J (2000) Microbial endophytes. CRC press

Bahadur I, Maurya BR, Kumar A, Meena VS, Raghuwanshi R (2016) Towards the soil sustainability and potassium-solubilizing microorganisms. In: Meena VS, Maurya BR, Verma JP, Meena RS (eds) Potassium solubilizing microorganisms for sustainable agriculture. Springer India, New Delhi, pp 255-266

Bakri Y, Masson M, Thonart P (2010) Isolation and identification of two new fungal strains for xylanase production. Appl Biochem Biotechnol 162:1626-1634

Banu AR, Devi MK, Gnanaprabhal G, Pradeep B, Palaniswamy M (2010) Production and characterization of pectinase enzyme from Penicillium chrysogenum. Indian J Sci Technol 3:377-381

Baranova A, Rogozhin E, Georgieva M, Bilanenko E, Kul'ko A, Yakushev A et al. (2019) Antimicrobial Peptides Produced by Alkaliphilic Fungi Emericellopsis alkalina: Biosynthesis and Biological Activity Against Pathogenic Multidrug-Resistant Fungi. Appl Biochem Microbiol 55:145-151

Baron NC, Rigobelo EC, Zied DC (2019) Filamentous fungi in biological control: current status and future perspectives. Chil J Agric Res 79:307-315

Baynes RE, Dedonder K, Kissell L, Mzyk D, Marmulak T, Smith G et al. (2016) Health concerns and management of select veterinary drug residues. Food Chem Toxicol 88:112-122

Begum N, Qin C, Ahanger MA, Raza S, Khan MI, 36
Ahmed N et al. (2019) Role of Arbuscular Mycorrhizal Fungi in Plant Growth Regulation: Implications in Abiotic Stress Tolerance. Front Plant Sci 10:1068

Beltagy EA, Rawway M, Abdul-Raouf UM, Elshenawy MA, Kelany MS (2018) Purification and characterization of theromohalophilic chitinase producing by halophilic Aspergillus flavus isolated from Suez Gulf. Egypt J Aquat Res 44:227-232

Bezerra J, Santos M, Svedese V, Lima D, Fernandes M, Paiva L et al. (2012) Richness of endophytic fungi isolated from Opuntia ficus-indica Mill.(Cactaceae) and preliminary screening for enzyme production. World J Microbiol Biotechnol 28:1989-1995

Bhattacharyya PN, Jha DK (2012) Plant growthpromoting rhizobacteria (PGPR): emergence in agriculture. World J Microbiol Biotechnol 28:13271350

Bilal L, Asaf S, Hamayun M, Gul H, Iqbal A, Ullah I et al. (2018) Plant growth promoting endophytic fungi Asprgillus fumigatus TS1 and Fusarium proliferatum BRL1 produce gibberellins and regulates plant endogenous hormones. Symbiosis 1-11

Bischof RH, Ramoni J, Seiboth B (2016) Cellulases and beyond: the first 70 years of the enzyme producer Trichoderma reesei. Microb Cell Fact 15:106

Blanchette RA, Held BW, Abdel-Azeem AM (2017) New record of Chaetomium iranianum MF787598 (Chaetomiaceae) for the Egyptian and African mycobiota. Microb Biosyst 2:6-9

Boivin S, Fonouni-Farde C, Frugier F (2016) How auxin and cytokinin phytohormones modulate root microbe interactions. Front Plant Sci 7:1240

Bononi L, Chiaramonte JB, Pansa CC, Moitinho MA, Melo IS (2020) Phosphorus-solubilizing Trichoderma spp. from Amazon soils improve soybean plant growth. Sci Rep 10:1-13

Broadley MR, White PJ, Hammond JP, Zelko I, Lux A (2007) Zinc in plants. New Phytol 173:677-702

Buxdorf K, Rahat I, Gafni A, Levy M (2013) The epiphytic fungus Pseudozyma aphidis induces jasmonic acid-and salicylic acid/nonexpressor of PR1independent local and systemic resistance. Plant physiol 161:2014-2022

Cakmak I (2008) Enrichment of cereal grains with zinc: agronomic or genetic biofortification? Plant soil 302:1-17

Cakmak I (2010) Biofortification of cereals with zinc and iron through fertilization strategy. In: Gilkes R, 19th World Congress of Soil Science, Brisbane

Chadha N, Prasad R, Varma A (2015) Plant promoting activities of fungal endophytes associated with tomato roots from central Himalaya, India and their 
interaction with Piriformospora indica. Int J Pharm Bio Sci 6:333-343

Chamekh R, Deniel F, Donot C, Jany J-L, Nodet P, Belabid L (2019) Isolation, identification and enzymatic activity of halotolerant and halophilic fungi from the Great Sebkha of Oran in Northwestern of Algeria. Mycobiology 47:230-241

Chandra P, Arora DS, Pal M, Sharma RK (2018) Antioxidant potential and extracellular auxin production by white rot fungi. Appl Biochem Biotechnol 1-9

Compant S, Duffy B, Nowak J, Clément C, Barka EA (2005) Use of plant growth-promoting bacteria for biocontrol of plant diseases: principles, mechanisms of action, and future prospects. Appl Environ Microbiol 71:4951-4959

Cosme M, Ramireddy E, Franken P, Schmülling T, Wurst S (2016) Shoot-and root-borne cytokinin influences arbuscular mycorrhizal symbiosis. Mycorrhiza 26:709-720

Cutler SR, Rodriguez PL, Finkelstein RR, Abrams SR (2010) Abscisic acid: emergence of a core signaling network. Ann Rev Plant Biol 61:651-679

De Briyne N, Atkinson J, Pokludová L, Borriello S (2014) Antibiotics used most commonly to treat animals in Europe. Vet Rec 175:325

de Cassia Pereira J, Paganini Marques N, Rodrigues A, Brito de Oliveira T, Boscolo M, Da Silva R et al. (2015) Thermophilic fungi as new sources for production of cellulases and xylanases with potential use in sugarcane bagasse saccharification. J Appl Microbiol 118:928-939

De Silva NI, Brooks S, Lumyong S, Hyde KD (2019) Use of endophytes as biocontrol agents. Fungal Biol Rev 33:133-148

Dervinis C, Frost CJ, Lawrence SD, Novak NG, Davis JM (2010) Cytokinin primes plant responses to wounding and reduces insect performance. J Plant Growth Reg 29:289-296

Deswal D, Khasa YP, Kuhad RC (2011) Optimization of cellulase production by a brown rot fungus Fomitopsis sp. RCK2010 under solid state fermentation. Biores Technol 102:6065-6072.

Diep CN, Hieu TN (2013) Phosphate and potassium solubilizing bacteria from weathered materials of denatured rock mountain, Ha Tien, Kiên Giang province Vietnam. Am J Life Sci 1:88-92

Din M, Nelofer R, Salman M, Khan FH, Khan A, Ahmad $M$ et al. (2019) Production of nitrogen fixing Azotobacter (SR-4) and phosphorus solubilizing Aspergillus niger and their evaluation on Lagenaria siceraria and Abelmoschus esculentus. Biotechnol Rep 22:e00323
Dixon R, Kahn D (2004) Genetic regulation of biological nitrogen fixation. Nat Rev Microbiol 2:621-631

Dolatabad HK, Javan-Nikkhah M, Shier WT (2017) Evaluation of antifungal, phosphate solubilisation, and siderophore and chitinase release activities of endophytic fungi from Pistacia vera. Mycol Prog 16:777-790

Egamberdieva D, Wirth SJ, Alqarawi AA, Abd_Allah EF, Hashem A (2017) Phytohormones and beneficial microbes: essential components for plants to balance stress and fitness. Front Microbiol 8:2104

El Enshasy HA, Elsayed EA, Suhaimi N, Malek RA, Esawy M (2018) Bioprocess optimization for pectinase production using Aspergillus niger in a submerged cultivation system. BMC Biotechnol 18:71

Englbrecht CC, Schoof H, Böhm S (2004) Conservation, diversification and expansion of $\mathrm{C} 2 \mathrm{H} 2$ zinc finger proteins in the Arabidopsis thaliana genome. BMC genom 5:39

Farias CP, CARVALHO RC, Resende FM, Azevedo LC (2018) Consortium of five fungal isolates conditioning root growth and arbuscular mycorrhiza in soybean, corn, and sugarcane. An Acad Bras Cienc 90:36493660

Farjana A, Zerin N, Kabir MS (2014) Antimicrobial activity of medicinal plant leaf extracts against pathogenic bacteria.Asian Pac J Trop Dis 4:S920S923

Finkelstein R (2013) Abscisic acid synthesis and response. The Arabidopsis book/American American Soc Plant Biol 11

Finley RL, Collignon P, Larsson DJ, McEwen SA, Li XZ, Gaze WH et al. (2013) The scourge of antibiotic resistance: the important role of the environment. Clin Infect Dis 57:704-710

Fomina M, Alexander IJ, Colpaert J, Gadd G (2005) Solubilization of toxic metal minerals and metal tolerance of mycorrhizal fungi. Soil Biol Biochem 37:851-866

Fomina M, Alexander IJ, Hillier S, Gadd G (2004) Zinc phosphate and pyromorphite solubilization by soil plant-symbiotic fungi. Geomicrobiol J 21:351-366

Frąc M, Hannula SE, Bełka M, Jędryczka M (2018) Fungal biodiversity and their role in soil health. Front Microbiol 9:707

Fu S-F, Sun P-F, Lu H-Y, Wei J-Y, Xiao H-S, Fang W-T et al. (2016) Plant growth-promoting traits of yeasts isolated from the phyllosphere and rhizosphere of Drosera spatulata Lab. Fungal Biol 120:433-448

Gadd GM (2007) Geomycology: biogeochemical transformations of rocks, minerals, metals and radionuclides by fungi, bioweathering and bioremediation. Mycol Res 111:3-49 
Gajera H, Katakpara ZA, Patel S, Golakiya B (2016) Antioxidant defense response induced by Trichoderma viride against Aspergillus niger Van Tieghem causing collar rot in groundnut (Arachis hypogaea L.). Microb pathog 91:26-34

Gamalero E, Berta G, Massa N, Glick BR, Lingua G (2008) Synergistic interactions between the ACC deaminase-producing bacterium Pseudomonas putida UW4 and the AM fungus Gigaspora rosea positively affect cucumber plant growth. FEMS Microbiol Ecol 64:459-467

Geetha M, Saranraj P, Mahalakshmi S, Reetha D (2012) Screening of pectinase producing bacteria and fungi for its pectinolytic activity using fruit wastes. Int $\mathbf{J}$ Biochem Biotech Sci 1:30-42

Ghosh SK, Banerjee S, Sengupta C (2017) Bioassay, characterization and estimation of siderophores from some important antagonistic Fungi. J Biopes 10:105112

Gillings MR (2013) Evolutionary consequences of antibiotic use for the resistome, mobilome and microbial pangenome. Front Microbiol 4:4

Gizaw B, Tsegay Z, Tefera G, Aynalem E, Wassie M, Abatneh E (2017) Phosphate solubilizing fungi isolated and characterized from Teff rhizosphere soil collected from North Showa zone, Ethiopia. Afric J Microbiol Res11:687-696

Glick BR (2014) Bacteria with ACC deaminase can promote plant growth and help to feed the world. Microb Res 169:30-39

Glick BR, Todorovic B, Czarny J, Cheng Z, Duan J, McConkey B (2007) Promotion of plant growth by bacterial ACC deaminase. Crit Rev Plant Sci 26:227242

Gofar N (2013) Characterization of petroleum hydrocarbon decomposing fungi isolated from mangrove rhizosphere. J Trop Soil 16:39-45

Gond SK, Mishra A, Sharma VK, Verma SK, Kumar J, Kharwar RN et al. (2012) Diversity and antimicrobial activity of endophytic fungi isolated from Nyctanthes arbor-tristis, a well-known medicinal plant of India. Mycoscience 53:113-121

González-Abradelo D, Pérez-Llano Y, Peidro-Guzmán H, del Rayo Sánchez-Carbente M, Folch-Mallol JL, Aranda E et al. (2019) First demonstration that ascomycetous halophilic fungi (Aspergillus sydowii and Aspergillus destruens) are useful in xenobiotic mycoremediation under high salinity conditions. Biores Technol 279:287-296

Govumoni SP, Gentela J, Koti S, Haragopal V, Venkateshwar S, Rao LV (2015) Extracellular lignocellulolytic enzymes by Phanerochaete chrysosporium (MTCC 787) under solid-state fermentation of agro wastes. Int J Curr Microbiol App Sci 4:700-710

Gu K, Pavagadhi SI, Chen C-Y, Yeap YT, Swarup S, Naqvi NI (2020) Crosskingdom growth benefits of fungus-derived phytohormones in Choy Sum bioRxiv

Gundala P, Chinthala P, Sreenivasulu B (2013) A new facultative alkaliphilic, potassium solubilizing, Bacillus Sp. SVUNM9 isolated from mica cores of Nellore District, Andhra Pradesh, India. Research and Reviews. J Microbiol Biotechnol 2:1-7

Gupta G, Parihar SS, Ahirwar NK, Snehi SK, Singh V (2015) Plant growth promoting rhizobacteria (PGPR): current and future prospects for development of sustainable agriculture. J Microb Biochem Technol 7:096-102

Hajji-Hedfi L, Regaieg H, Larayedh A, Chihani N, Horrigue-Raouani N (2018) Biological control of wilt disease complex on tomato crop caused by Meloidogyne javanica and Fusarium oxysporum f. sp. lycopersici by Verticillium leptobactrum. Environ Sci Pollut Res 25:18297-18302

Hambidge KM, Krebs NF (2007) Zinc deficiency: a special challenge. J Nut 137:1101-1105

Hamzah TNT, Lee SY, Hidayat A, Terhem R, FaridahHanum I, Mohamed R (2018) Diversity and characterization of endophytic fungi isolated from the tropical mangrove species, Rhizophora mucronata, and identification of potential antagonists against the soil-borne fungus, Fusarium solani. Front Microbiol 9:1707

Hartley SE, Gange AC (2009) Impacts of plant symbiotic fungi on insect herbivores: mutualism in a multitrophic context. Ann Rev Entomol 54:323-342

Hasan H (2002) Gibberellin and auxin production by plant root-fungi and their biosynthesis under salinitycalcium interaction. Rostlinna vyroba 48:101-106

He R, Ding R, Heyman JA, Zhang D, Tu R (2019) Ultrahigh-throughput picoliter-droplet microfluidics screening of the industrial cellulase-producing filamentous fungus Trichoderma reesei. J Indust Microbiol Biotechnol 46:1603-1610

Higginbotham SJ, Arnold AE, Ibañez A, Spadafora C, Coley PD, Kursar TA (2013) Bioactivity of fungal endophytes as a function of endophyte taxonomy and the taxonomy and distribution of their host plants. PloS one 8

Hu YF, Zhou G, Na XF, Yang L, Nan WB, Liu X et al. (2013) Cadmium interferes with maintenance of auxin homeostasis in Arabidopsis seedlings. J Plant Physiol 170:965-975

Hussain A, Zahir ZA, Asghar HN, Ahmad M, Jamil M, Naveed $M$ et al. (2018) Zinc solubilizing bacteria for zinc biofortification in cereals: a step toward 
sustainable nutritional security. In: Meena VS (ed) Role of rhizospheric microbes in soil. Springer Singapore, pp 203-227

Iqbal M, Ashraf M (2013) Gibberellic acid mediated induction of salt tolerance in wheat plants: Growth, ionic partitioning, photosynthesis, yield and hormonal homeostasis. Environ Exp Bot 86:76-85

Iqbal MA, Khalid M, Shahzad SM, Ahmad M, Soleman N, Akhtar N (2012) Integrated use of Rhizobium leguminosarum, plant growth promoting rhizobacteria and enriched compost for improving growth, nodulation and yield of lentil (Lens culinaris Medik.). Chil J Agric Res 72:104

Iqbal U, Jamil N, Ali I, Hasnain S (2010) Effect of zincphosphate-solubilizing bacterial isolates on growth of Vigna radiata. Ann microbiol 60:243-248

Irfan M, Nadeem M, Syed Q (2014) One-factor-at-a-time (OFAT) optimization of xylanase production from Trichoderma viride-IR05 in solid-state fermentation. J Radiat Res Appl Sci 7:317-326

Iswarya B, Ramesh KV (2019) Promising Antimicrobial Compounds from an Endophytic Fungus Penicillium daleae EF 4 Isolated from the Seaweed Enteromorpha flexuosa Linn. Research \& Reviews: A J Microbiol Virol 9:26-39

Jain R, Saxena J, Sharma V (2012a) Effect of phosphatesolubilizing fungi Aspergillus awamori S29 on mungbean (Vigna radiata cv. RMG 492) growth. Folia Microbiol 57:533-541

Jain R, Saxena J, Sharma V (2012b) Solubilization of inorganic phosphates by Aspergillus awamori S19 isolated from rhizosphere soil of a semi-arid region. Ann Microbiol 62:725-735

Jaroszuk-Ściseł J, Kurek E, Trytek M (2014) Efficiency of indoleacetic acid, gibberellic acid and ethylene synthesized in vitro by Fusarium culmorum strains with different effects on cereal growth. Biologia 69:281-292

Jiang Y, Shang Y, Yang K, Wang H (2016) Phenol degradation by halophilic fungal isolate JS4 and evaluation of its tolerance of heavy metals. Appl Microbiol Biotechnol 100:1883-1890

Kaewchai S (2009) Mycofungicides and fungal biofertilizers. Fungal Divers 38: 25-50

Kanna M, Yano S, Inoue H, Fujii T, Sawayama S (2011) Enhancement of $\beta$-xylosidase productivity in cellulase producing fungus Acremonium cellulolyticus. AMB Exp 1:1-8

Karmakar P, Sharma D, Das P, Saha AK (2018) phosphate solubilizing capacity and siderophore production by Arthroderma Cuniculi Dawson 1963 isolated from rhizospheric soil. Res J Life Sci Bioinform Pharma Chem Sci
Karthikeyan P, Kanimozhi K, Senthilkumar G, Panneerselvam A, Ashok G (2014) Optimization of enzyme production in Trichoderma viride using carbon and nitrogen source. Int J Curr Microbiol App Sci 3:88-95

Karun NC, Bhagya BS, Sridhar KR (2018) Biodiversity of macrofungi in Yenepoya campus, Southwest India. Microb Biosyst 3:1-11

Karunasinghe T, Maharachchikumbura S, Rethinasamy V, Al-Sadi AM (2020) Antagonistic activity of endophytic and rhizosphere fungi isolated from sea purslane (Sesuvium portulacastrum) against Pythium damping-off of cucumber. Plant Disease

Karwehl S, Stadler M (2016) Exploitation of fungal biodiversity for discovery of novel antibiotics. In: Stadler M, Dersch P (eds) How to Overcome the Antibiotic Crisis. Springer International Publishing, Cham, pp 303-338

Kasana RC, Panwar NR, Burman U, Pandey CB, Kumar $P$ (2017) Isolation and Identification of Two Potassium Solubilizing Fungi from Arid Soil. Int $\mathbf{J}$ Curr Microbiol Appl Sci 6:1752-1762

Kazan K (2013) Auxin and the integration of environmental signals into plant root development. Ann Bot112:1655-1665

Kende H (1993) Ethylene biosynthesis. Ann Rev Plant Biol 44:283-307

Keshavarz Zarjani J, Aliasgharzad N, Oustan S, Emadi M, Ahmadi A (2013) Isolation and characterization of potassium solubilizing bacteria in some Iranian soils. Arch Agron Soil Sci 59:1713-1723

Khan AR, Ullah I, Waqas M, Shahzad R, Hong S-J, Park G-S et al. (2015) Plant growth-promoting potential of endophytic fungi isolated from Solanum nigrum leaves. World J Microbiol Biotechnol 31:1461-1466

Kharwar RN, Gond SK, Kumar A, Mishra A (2010) A comparative study of endophytic and epiphytic fungal association with leaf of Eucalyptus citriodora Hook., and their antimicrobial activity. World J Microbiol Biotechnol26:1941-1948

Kharwar RN, Verma SK, Mishra A, Gond SK, Sharma VK, Afreen T et al. (2011) Assessment of diversity, distribution and antibacterial activity of endophytic fungi isolated from a medicinal plant Adenocalymma alliaceum Miers. Symbiosis 55:39-46

Khatabi B, Molitor A, Lindermayr C, Pfiffi S, Durner J, Von Wettstein D et al. (2012) Ethylene supports colonization of plant roots by the mutualistic fungus Piriformospora indica. PLoS One 7

Khatabi B, Schäfer P (2012) Ethylene in mutualistic symbioses. Plant signal Behav 7:1634-1638

Kobayashi T, Nishizawa NK (2012) Iron uptake, translocation, and regulation in higher plants. Ann 
Rev Plant Biol 63:131-152

Kogej T, Ramos J, Plemenitaš A, Gunde-Cimerman N (2005) The halophilic fungus Hortaea werneckii and the halotolerant fungus Aureobasidium pullulans maintain low intracellular cation concentrations in hypersaline environments. Appl Environ Microbiol 71:6600-6605

Kotowski M (2019) History of mushroom consumption and its impact on traditional view on mycobiota-an example from Poland. Microbial Biosytems 4:1-13

Kour D, Rana KL, Yadav AN, Sheikh I, Kumar V, Dhaliwal HS et al. (2020a) Amelioration of drought stress in Foxtail millet (Setaria italica L.) by Psolubilizing drought-tolerant microbes with multifarious plant growth promoting attributes. Environ Sustain 3:23-34

Kour D, Rana KL, Yadav AN, Yadav N, Kumar M, Kumar V et al. (2020b) Microbial biofertilizers: Bioresources and eco-friendly technologies for agricultural and environmental sustainability. Biocatal Agric Biotechnol 23:101487

Kour D, Rana KL, Yadav N, Yadav AN, Singh J, Rastegari AA et al. (2019a) Agriculturally and industrially important fungi: current developments and potential biotechnological applications. In: Yadav AN, Singh S, Mishra S, Gupta A (eds) Recent Advancement in White Biotechnology through Fungi, Volume 2: Perspective for Value-Added Products and Environments. Springer International Publishing, Cham, pp 1-64. doi:https://doi.org/10.1007/978-3030-14846-1_1

Kour D, Rana KL, Yadav N, Yadav AN, Singh J, Rastegari AA et al. (2019b) Agriculturally and Industrially Important Fungi: Current Developments and Potential Biotechnological Applications. In: Yadav AN, Singh S, Mishra S, Gupta A (eds) Recent Advancement in White Biotechnology Through Fungi: Volume 2: Perspective for Value-Added Products and Environments. Springer International Publishing, Cham, pp 1-64. doi:10.1007/978-3-03014846-1_1

Kumar CS, Jacob T, Devasahayam S, Thomas S, Geethu C (2018) Multifarious plant growth promotion by an entomopathogenic fungus Lecanicillium psalliotae. Microbiol Res 207:153-160

Kumar S, Kaushik N (2013) Endophytic fungi isolated from oil-seed crop Jatropha curcas produces oil and exhibit antifungal activity. PloS one 8

Kumawat N, Kumar R, Khandkar U, Yadav R, Saurabh $\mathrm{K}$, Mishra J et al. (2019) Silicon (Si)-and Zinc (Zn)Solubilizing Microorganisms: Role in Sustainable Agriculture. In: Giri B, Prasad R, Wu QS, Varma A (eds) Biofertilizers for Sustainable Agriculture and
Environment. Springer, pp 109-135

Larran S, Simon MR, Moreno MV, Siurana MS, Perelló A (2016) Endophytes from wheat as biocontrol agents against tan spot disease. Biol Contr 92:17-23

Lee H, Lee YM, Jang Y, Lee S, Lee H, Ahn BJ et al. (2014) Isolation and analysis of the enzymatic properties of thermophilic fungi from compost. Mycobiology 42:181-184

Lee SH, Hosseindoust A, Laxman Ingale S, Rathi PC, Yoon SY, Choi JW et al. (2020) Thermostable xylanase derived from Trichoderma citrinoviride increases growth performance and non-starch polysaccharide degradation in broiler chickens. British Poult Sci 61:57-62

Li J, Zhang Y, Li J, Sun T, Tian C (2020) Metabolic engineering of the cellulolytic thermophilic fungus Myceliophthora thermophila to produce ethanol from cellobiose. Biotechnol Biofuel 13:23

Li Y, Cui F, Liu Z, Xu Y, Zhao H (2007) Improvement of xylanase production by Penicillium oxalicum $\mathrm{ZH}-$ 30 using response surface methodology. Enzym MicrobTechnol 40:1381-1388

Li Z, Bai T, Dai L, Wang F, Tao J, Meng S et al. (2016a) A study of organic acid production in contrasts between two phosphate solubilizing fungi: Penicillium oxalicum and Aspergillus niger. Sci Rep 6:1-8

Li Z, Bai T, Dai L, Wang F, Tao J, Meng S et al. (2016b) A study of organic acid production in contrasts between two phosphate solubilizing fungi: Penicillium oxalicum and Aspergillus niger. Sci Rep 6:25313

Lian B, Fu P, Mo D, Liu C (2002) A comprehensive review of the mechanism of potassium release by silicate bacteria. Acta Mineral Sinc 22:179-183

Lima JMS, Pereira JO, Batista IH, Neto PdQC, dos Santos JC, de Araújo SP et al. (2016) Potential biosurfactant producing endophytic and epiphytic fungi, isolated from macrophytes in the Negro River in Manaus, Amazonas, Brazil. Afri J Biotechnol 15:1217-1223

Limtong S, Into P, Attarat P (2020) Biocontrol of Rice Seedling Rot Disease Caused by Curvularia lunata and Helminthosporium oryzae by Epiphytic Yeasts from Plant Leaves. Microorganisms 8:647

Linke R, Thallinger GG, Haarmann T, Eidner J, Schreiter M, Lorenz P et al. (2015) Restoration of female fertility in Trichoderma reesei QM6a provides the basis for inbreeding in this industrial cellulase producing fungus. Biotechnol Biofuels 8:155

Ljung K (2013) Auxin metabolism and homeostasis during plant development. Development 140:943-950

Lo Presti L, Lanver D, Schweizer G, Tanaka S, Liang L, Tollot $M$ et al. (2015) Fungal effectors and plant susceptibility. Ann Rev Plant Biol 66:513-545 
López-Ráez JA (2016) How drought and salinity affect arbuscular mycorrhizal symbiosis and strigolactone biosynthesis? Planta 243:1375-1385

Luo H, Wang Y, Wang H, Yang J, Yang Y, Huang H et al. (2009) A novel highly acidic $\beta$-mannanase from the acidophilic fungus Bispora sp. MEY-1: gene cloning and overexpression in Pichia pastoris. Appl Microbiol Biotechnol 82:453-461

Maggio A, Barbieri G, Raimondi G, De Pascale S (2010) Contrasting effects of GA 3 treatments on tomato plants exposed to increasing salinity. J Plant Growth Reg 29:63-72

Maijala P, Kango N, Szijarto N, Viikari L (2012) Characterization of hemicellulases from thermophilic fungi. Antonie Van Leeuwenhoek 101:905-917

Malviya J, Singh K, Joshi V (2011) Effect of phosphate solubilizing fungi on growth and nutrient uptake of ground nut (Arachis hypogaea) plants. Adv Biores 2:110-113

Manjili FA, Sedghi M, Pessarakli M (2012) Effects of phytohormones on proline content and antioxidant enzymes of various wheat cultivars under salinity stress. J Plant Nut 35:1098-1111

Martin N, Guez M, Sette L, Da Silva R, Gomes E (2010) Pectinase production by a Brazilian thermophilic fungus Thermomucor indicae-seudaticae N31 in solid-state and submerged fermentation. Microbiology 79:306-313

Martínez JL (2012) Natural antibiotic resistance and contamination by antibiotic resistance determinants: the two ages in the evolution of resistance to antimicrobials. Front Microbiol 3:1

Martino E, Perotto S, Parsons R, Gadd GM (2003) Solubilization of insoluble inorganic zinc compounds by ericoid mycorrhizal fungi derived from heavy metal polluted sites. Soil Biol Biochem 35:133-141

Maurya BR, Kumar A, Raghuwanshi R, Bahadur I, Meena V (2015) Effect of phosphate solubilizing isolates on growth, yield and phosphate acquisition by rice and wheat crops. Afr J Microbiol Res 9:13671375

Meena V, Maurya B, Bahadur I (2014a) Potassium solubilization by bacterial strain in waste mica. Bangladesh J Bot 43:235-237

Meena VS, Maurya B, Verma JP (2014b) Does a rhizospheric microorganism enhance $\mathrm{K}+$ availability in agricultural soils? Microbiol Res 169:337-347

Mefteh FB, Daoud A, Chenari Bouket A, Alenezi FN, Luptakova L, Rateb ME et al. (2017) Fungal root microbiome from healthy and brittle leaf diseased date palm trees (Phoenix dactylifera L.) reveals a hidden untapped arsenal of antibacterial and broad spectrum antifungal secondary metabolites. Front Microbiol

\section{8:307}

Mehmood A, Khan N, Irshad M, Hamayun M (2018) IAA Producing Endopytic Fungus Fusariun oxysporum wlw Colonize Maize Roots and Promoted Maize Growth Under Hydroponic Condition. Eur Exp Biol 8:24

Milić N, Milanović M, Letić NG, Sekulić MT, Radonić J, Mihajlović I et al. (2013) Occurrence of antibiotics as emerging contaminant substances in aquatic environment. Int J Environ Health Res 23:296-310

Moghaddam MSH, Soltani J (2014) Psychrophilic endophytic fungi with biological activity inhabit Cupressaceae plant family. Symbiosis 63:79-86

Mohammadi K, Sohrabi Y (2012) Bacterial biofertilizers for sustainable crop production: a review. ARPN J Agric Biol Sci 7:307-316

Mohanty S, Ghosh S, Nayak S, Das A (2017) Isolation, Identification and Screening of Manganese Solubilizing Fungi from Low-Grade Manganese Ore Deposits. Geomicrobiol J 34:309-316

Mohapatra PK, Panigrahi R, Turner NC (2011) Physiology of spikelet development on the rice panicle: Is manipulation of apical dominance crucial for grain yield improvement? In: Sparks DL (ed) Advances in agronomy, vol 110. Elsevier, pp 333-359

Mouchacca J (2016) Mycological discoveries in the Middle East region in the second part of the last century. Microb Biosyst 1:1-39

Mukherjee R, Paul T, Soren JP, Halder SK, Mondal KC, Pati BR et al. (2019) Acidophilic $\alpha$-amylase production from Aspergillus niger RBP7 using potato peel as substrate: a waste to value added approach. Waste and biomass valorization 10:851-863

Mukhopadhyay SK, Chatterjee S, Gauri SS, Das SS, Mishra A, Patra M et al. (2014) Isolation and characterization of extracellular polysaccharide Thelebolan produced by a newly isolated psychrophilic Antarctic fungus Thelebolus. Carbohydr polym 104:204-212

Murali M, Amruthesh K, Sudisha J, Niranjana S, Shetty $\mathrm{H}$ (2012) Screening for plant growth promoting fungi and their ability for growth promotion and induction of resistance in pearl millet against downy mildew disease. J Phytol

Mwajita MR, Murage H, Tani A, Kahangi EM (2013) Evaluation of rhizosphere, rhizoplane and phyllosphere bacteria and fungi isolated from rice in Kenya for plant growth promoters. SpringerPlus 2:606 Nadeem SM, Ahmad M, Zahir ZA, Ashraf M (2012) Microbial ACC-deaminase biotechnology: perspectives and applications in stress agriculture. In Maheshwari DK (ed) Bacteria in Agrobiology: Stress Management. Springer Berlin Heidelberg, Berlin, 
Heidelberg, pp 141-185

Nadeem SM, Naveed M, Zahir ZA, Asghar HN (2013) Plant-microbe interactions for sustainable agriculture: fundamentals and recent advances. In Arora NK (ed) Plant microbe symbiosis: fundamentals and advances. Springer India, New Delhi, pp 51-103

Nutaratat P, Srisuk N, Arunrattiyakorn P, Limtong S (2014) Plant growth-promoting traits of epiphytic and endophytic yeasts isolated from rice and sugar cane leaves in Thailand. Fungal Biol 118:683-694

Oggerin M, Tornos F, Rodríguez N, Del Moral C, Sánchez- Román M, Amils R (2013) Specific jarosite biomineralization by Purpureocillium lilacinum, an acidophilic fungus isolated from R ío T into. Environ Microbiol 15:2228-2237

Olszewski N, Sun T-p, Gubler F (2002) Gibberellin signaling: biosynthesis, catabolism, and response pathways. Plant Cell 14: S61-S80

Ortiz GE, Ponce-Mora MC, Noseda DG, Cazabat G, Saravalli C, López MC et al. (2017) Pectinase production by Aspergillus giganteus in solid-state fermentation: optimization, scale-up, biochemical characterization and its application in olive-oil extraction. J Indus Microbiol Biotechnol 44:197-211

Pan W-Z, Huang X-W, Wei K-B, Zhang C-M, Yang DM, Ding J-M et al. (2010) Diversity of thermophilic fungi in Tengchong Rehai National Park revealed by ITS nucleotide sequence analyses. J Microbiol 48:146-152

Pandey A, Das N, Kumar B, Rinu K, Trivedi P (2008) Phosphate solubilization by Penicillium spp. isolated from soil samples of Indian Himalayan region. World J Microbiol Biotechnol24:97-102

Park Y, Kang S, Lee J, Hong S, Kim S (2002) Xylanase production in solid state fermentation by Aspergillus niger mutant using statistical experimental designs. Appl Microbiol Biotechnol58:761-766

Parmar P, Sindhu S (2013) Potassium solubilization by rhizosphere bacteria: influence of nutritional and environmental conditions. J Microbiol Res 3:25-31

Patil PM, Kuligod V, Hebsur N, Patil C, Kulkarni G (2012) Effect of phosphate solubilizing fungi and phosphorus levels on growth, yield and nutrient content in maize (Zea mays). Karnataka J Agric Sci 25

Peleg Z, Blumwald E (2011) Hormone balance and abiotic stress tolerance in crop plants. Curr Opin Plant Biol 14: 290-295

Peskan- Berghöfer T, Vilches- Barro A, Müller TM, Glawischnig E, Reichelt M, Gershenzon $\mathrm{J}$ et al. (2015) Sustained exposure to abscisic acid enhances the colonization potential of the mutualist fungus Piriformospora indica on Arabidopsis thaliana roots.
New Phytol 208:873-886

Phitsuwan P, Laohakunjit N, Kerdchoechuen O, Kyu KL, Ratanakhanokchai K (2013) Present and potential applications of cellulases in agriculture, biotechnology, and bioenergy. Folia Microbiol 58:163-176

Potshangbam M, Devi SI, Sahoo D, Strobel GA (2017) Functional characterization of endophytic fungal community associated with Oryza sativa L. and Zea mays L. Front Microbiol 8:325

Prajapati K, Sharma M, Modi H (2012) Isolation of two potassium solubilizing fungi from ceramic industry soils. Life Sci Leaflets 5:71-75

Prajapati K, Sharma M, Modi H (2013) Growth promoting effect of potassium solubilizing microorganisms on Abelmoscus esculantus. Int $\mathbf{J}$ Agric Sci 3:181-188

Priyadharsini P, Muthukumar T (2016) Interactions between arbuscular mycorrhizal fungi and potassiumsolubilizing microorganisms on agricultural productivity. In: Meena VS, Maurya BR, Verma JP, Meena RS (eds) Potassium solubilizing microorganisms for sustainable agriculture. Springer, pp 111-125

Qadri M, Johri S, Shah BA, Khajuria A, Sidiq T, Lattoo SK et al. (2013) Identification and bioactive potential of endophytic fungi isolated from selected plants of the Western Himalayas. SpringerPlus 2:8

Qi W, Zhao L (2013) Study of the siderophore- producing Trichoderma asperellum Q1 on cucumber growth promotion under salt stress. J Basic Microbiol 53:355-364

Qin Y, He H, Li N, Ling M, Liang Z (2010) Isolation and characterization of a thermostable cellulase-producing Fusarium chlamydosporum. World J Microbiol Biotechnol 26:1991-1997

Raghavendra M, Nayaka SC, Nuthan B (2016) Role of rhizosphere microflora in potassium solubilization. In: Meena VS, Maurya BR, Verma JP, Meena RS (eds) Potassium solubilizing microorganisms for sustainable agriculture. Springer India, New Delhi, pp 43-59

Ram H, Malik S, Dhaliwal S, Kumar B, Singh Y (2015) Growth and productivity of wheat affected by phosphorus-solubilizing fungi and phosphorus levels. Plant Soil Environ 61:122-126

Rana KL, Kour D, Kaur T, Sheikh I, Yadav AN, Kumar $\mathrm{V}$ et al. (2020a) Endophytic microbes from diverse wheat genotypes and their potential biotechnological applications in plant growth promotion and nutrient uptake. Proc Natl Acad Sci India B doi:10.1007/s40011-020-01168-0

Rana KL, Kour D, Sheikh I, Yadav N, Yadav AN, Kumar $\mathrm{V}$ et al. (2019) Biodiversity of endophytic fungi from 
diverse niches and their biotechnological applications. In: Singh BP (ed) Advances in Endophytic Fungal Research: Present Status and Future Challenges. Springer International Publishing, Cham, pp 105-144. doi:10.1007/978-3-030-03589-1_6

Rana KL, Kour D, Yadav N, Yadav AN (2020b) Endophytic microbes in nanotechnology: Current development, and potential biotechnology applications. In: Kumar A, Singh VK (eds) Microbial Endophytes. Woodhead Publishing, Cambridge, MA, pp 231-262. doi:https://doi.org/10.1016/B978-0-12818734-0.00010-3

Rashad H, Abdel-Azeem AM (2017) Lake Manzala Egypt, a bibliography: II-Microbiological studies. Microb Biosyst 2:1-5

Rastegari AA, Yadav AN, Yadav N (2020) Trends of microbial biotechnology for sustainable agriculture and biomedicine systems: Diversity and functional perspectives Elsevier, Amsterdam

Reineke G, Heinze B, Schirawski J, Buettner H, Kahmann R, Basse CW (2008) Indole- 3- acetic acid (IAA) biosynthesis in the smut fungus Ustilago maydis and its relevance for increased IAA levels in infected tissue and host tumour formation. Mol Plant Pathol 9:339-355

Ribeiro SFL, da Costa G, dos Santos HED, Montoya QV, Rodrigues A, de Oliveira JM et al. (2018) Antimicrobial activity of crude extracts of endophytic fungi from Oryctanthus alveolatus (Kunth) Kuijt (Mistletoe). Afr J Microbiol Res 12:263-268

Rodriguez RJ, Henson J, Van Volkenburgh E, Hoy M, Wright L, Beckwith F et al. (2008) Stress tolerance in plants via habitat-adapted symbiosis. The ISME J 2:404-416

Ruangsanka S (2014) Identification of phosphatesolubilizing fungi from the asparagus rhizosphere as antagonists of the root and crown rot pathogen Fusarium oxysporum. Sci Asia 40:16-20

Sah SK, Reddy KR, Li J (2016) Abscisic acid and abiotic stress tolerance in crop plants. Front Plant Sci 7:571

Sairam R, Tyagi A (2004) Physiology and molecular biology of salinity stress tolerance in plants. Curr sci 407-421

Sandona K, Billingsley Tobias TL, Hutchinson MI, Natvig DO, Porras-Alfaro A (2019) Diversity of thermophilic and thermotolerant fungi in corn grain. Mycologia 111:719-729

Sandri IG, Lorenzoni CMT, Fontana RC, da Silveira MM (2013) Use of pectinases produced by a new strain of Aspergillus niger for the enzymatic treatment of apple and blueberry juice LWT-Food Sci Technol 51:469475

Sangeeth K, Bhai RS, Srinivasan V (2012) Paenibacillus 43 glucanolyticus, a promising potassium solubilizing bacterium isolated from black pepper (Piper nigrumL.) rhizosphere. J Spices Aromatic Crop 21:118-124

Saravanakumar K, MubarakAli D, Kathiresan K, Wang M-H (2018) An evidence of fungal derived 1aminocyclopropane-1-carboxylate deaminase promoting the growth of mangroves. Beni-Suef Univer J Basic Appl Sci

Saravanan V, Kumar MR, Sa T (2011) Microbial zinc solubilization and their role on plants. In: Maheshwari DK (ed) Bacteria in Agrobiology: Plant Nutrient Management. Springer Berlin Heidelberg, Berlin, Heidelberg, pp 47-63

Sarkar DJ, Mukherjee I, Shakil NA, Rana VS, Kaushik P, Debnath S (2018) Antibiotics in agriculture: use and impact

Sati S, Pant P (2018) Evaluation of phosphate Solubilization by root endophytic aquatic Hyphomycete Tetracladium setigerum. Symbiosis:1-5

Schmit JP, Mueller GM (2007) An estimate of the lower limit of global fungal diversity. Biodivers Conser 16:99-111

Schmülling T (2002) New insights into the functions of cytokinins in plant development. J. Plant Growth Reg 21

Schrank A, Vainstein MH (2010) Metarhizium anisopliae enzymes and toxins. Toxicon 56:1267-1274

Shah AR, Madamwar D (2005) Xylanase production by a newly isolated Aspergillus foetidus strain and its characterization. Proc Biochem 40:1763-1771

Sharma A, Johri B (2003) Growth promoting influence of siderophore-producing Pseudomonas strains GRP3A and $\mathrm{PRS}^{\wedge}$ sub $9^{\wedge}$ in maize (Zea mays L.) under iron limiting conditions. Microbiolo Res 158:243

Sharma A, Soares C, Sousa B, Martins M, Kumar V, Shahzad B et al. (2019a) Nitric oxide- mediated regulation of oxidative stress in plants under metal stress: a review on molecular and biochemical aspects. Physiol plant

Sharma D, Pramanik A, Agrawal PK (2016) Evaluation of bioactive secondary metabolites from endophytic fungus Pestalotiopsis neglecta BAB-5510 isolated from leaves of Cupressus torulosa D. Don. 3 Biotech 6:210

Sharma S, Kour D, Rana KL, Dhiman A, Thakur S, Thakur P et al. (2019b) Trichoderma: Biodiversity, Ecological Significances, and Industrial Applications. In: Yadav AN, Mishra S, Singh S, Gupta A (eds) Recent Advancement in White Biotechnology Through Fungi: Volume 1: Diversity and Enzymes Perspectives. Springer, Cham, pp 85-120. doi:10.1007/978-3-030-10480-1_3 
Silva-Mendoza J, Gómez-Treviño A, López-Chuken U, Blanco-Gámez EA, Chávez-Guerrero L, CantúCárdenas ME (2020) Agave Leaves as a Substrate for the Production of Cellulases by Penicillium sp. and the Obtainment of Reducing Sugars. J Chem 2020

Simfukwe EJ, Tindwa HJ (2018) Rock phosphatesolubilising potential of fungal and bacterial isolates from soils surrounding panda Hill and Minjingu phosphate rock deposits in Tanzania. Trop Ecol 59:109-118

Sindhu SS, Sharma R, Sindhu S, Phour M (2019) Plant Nutrient Management Through Inoculation of ZincSolubilizing Bacteria for Sustainable Agriculture. In: Giri B, Prasad R, Wu QS, Varma A (eds) Biofertilizers for Sustainable Agriculture and Environment. Springer International Publishing, Cham, pp 173-201. doi:10.1007/978-3-030-18933-4_8

Singh A, Kumar R, Yadav AN, Mishra S, Sachan S, Sachan SG (2020) Tiny microbes, big yields: Microorganisms for enhancing food crop production sustainable development. In: Rastegari AA, Yadav AN, Yadav $\mathrm{N}$ (eds) Trends of Microbial Biotechnology for Sustainable Agriculture and Biomedicine Systems: Diversity and Functional Perspectives. Elsevier, Amsterdam, pp 1-15. doi:https://doi.org/10.1016/B978-0-12-8205266.00001-4

Singh H, Reddy MS (2011) Effect of inoculation with phosphate solubilizing fungus on growth and nutrient uptake of wheat and maize plants fertilized with rock phosphate in alkaline soils. Europ J Soil Biol 47:30-34

Singh R, Shelke G, Kumar A, Jha P (2015) Biochemistry and genetics of ACC deaminase: a weapon to "stress ethylene" produced in plants. Front Microbiol 6 (937): 2015

Singh RP, Jha P, Jha PN (2017) Bio-inoculation of plant growth-promoting rhizobacterium Enterobacter cloacae ZNP-3 increased resistance against salt and temperature stresses in wheat plant (Triticum aestivum L.). J Plant Growth Reg 36:783-798

Singh S, Prasad SM (2014) Growth, photosynthesis and oxidative responses of Solanum melongena $\mathrm{L}$. seedlings to cadmium stress: mechanism of toxicity amelioration by kinetin. Sci Horticul 176:1-10

Singh VK, Singh M, Singh SK, Kumar C, Kumar A (2019) Sustainable Agricultural Practices Using Beneficial Fungi Under Changing Climate Scenario. In Choudhary KK, Kumar A, Singh AK (eds) Climate Change and Agricultural Ecosystems. Elsevier Woodhead Publishing, pp 25-42. doi:https://doi.org/10.1016/B978-0-12-8164839.00002-5

Stein R, Duarte G, Spohr M, Lopes S, Fett J (2009) 44
Distinct physiological responses of two rice cultivars subjected to iron toxicity under field conditions. Ann Appl Biol 154:269-277

Strange RN, Scott PR (2005) Plant disease: a threat to global food security. Ann Revi phytopathol 43

Su X, Zhou M, Hu P, Xiao Y, Wang Z, Mei R et al. (2019) Whole-genome sequencing of an acidophilic Rhodotorula sp. ZM1 and its phenol-degrading capability under acidic conditions. Chemosphere 232:76-86

Subrahmanyam G, Kumar A, Sandilya SP, Chutia M, Yadav AN (2020) Diversity, plant growth promoting attributes, and agricultural applications of rhizospheric microbes. In: Yadav AN, Singh J, Rastegari AA, Yadav N (eds) Plant Microbiomes for Sustainable Agriculture. Springer, Cham, pp 1-52. doi:https://doi.org/10.1007/978-3-030-38453-1_1

Subramanian V, Schuster LA, Moore KT, Taylor LE, Baker JO, Vander Wall TA et al. (2017) A versatile 2A peptide-based bicistronic protein expressing platform for the industrial cellulase producing fungus, Trichoderma reesei. Biotechnol Biofuels 10:34

Suman A, Yadav AN, Verma P (2016a) Endophytic microbes in crops: diversity and beneficial impact for sustainable agriculture. In Singh DP, Singh HB, Prabha R (eds) Microbial Inoculants in Sustainable Agricultural Productivity: Vol. 1: Research Perspectives. Springer India, New Delhi, pp 117-143. doi:10.1007/978-81-322-2647-5_7

Suman A, Yadav AN, Verma P (2016b) Endophytic Microbes in Crops: Diversity and Beneficial Impact for Sustainable Agriculture. In: Singh DP, Singh HB, Prabha R (eds) Microbial Inoculants in Sustainable Agricultural Productivity: Vol. 1: Research Perspectives. Springer, New Delhi, pp 117-143. doi:https://doi.org/10.1007/978-81-322-2647-5_7

Sun P-F, Fang W-T, Shin L-Y, Wei J-Y, Fu S-F, Chou J$Y$ (2014) Indole-3-acetic acid-producing yeasts in the phyllosphere of the carnivorous plant Drosera indica L. PloS one 9

Supaphon P, Keawpiboon C, Preedanon S, Phongpaichit S, Rukachaisirikul V (2018) Isolation and antimicrobial activities of fungi derived from Nymphaea lotus and Nymphaea stellata. Mycoscience 59:415-423

Sutjaritvorakul T, Chutipaijit S, Sihanonth P (2017) Solubilization and bioprecipitation of zinc oxide nanoparticles by fungi isolated from zinc sulfide mineral ores. Materials Today: Proceedings 4:65626566

Tepe O, Dursun AY (2014) Exo-pectinase production by Bacillus pumilus using different agricultural wastes and optimizing of medium components using response 
surface methodology. Environ Sci Pollut Res 21:9911-9920

Thomas MB, Read AF (2007) Fungal bioinsecticide with a sting. Nat Biotechnol 25:1367-1368

Tiwari P, Bajpai M, Singh LK, Mishra S, Yadav AN (2020) Phytohormones producing fungal communities: Metabolic engineering for abiotic stress tolerance in crops. In: Yadav AN, Mishra S, Kour D, Yadav N, Kumar A (eds) Agriculturally Important Fungi for Sustainable Agriculture, Volume 1: Perspective for Diversity and Crop Productivity. Springer, Cham, pp 1-25. doi:https://doi.org/10.1007/978-3-030-45971-0_8

Tranier M-S, Pognant-Gros J, Quiroz RDlC, González CNA, Mateille T, Roussos S (2014) Commercial biological control agents targeted against plantparasitic root-knot nematodes. Braz Arch Biol Technol 57:831-841

Tsavkelova E, Oeser B, Oren-Young L, Israeli M, Sasson Y, Tudzynski B et al. (2012) Identification and functional characterization of indole-3-acetamidemediated IAA biosynthesis in plant-associated Fusarium species. Fungal Gen Biol 49:48-57

Tsuji M, Tanabe Y, Vincent WF, Uchida M (2019) Vishniacozyma ellesmerensis sp. nov., a psychrophilic yeast isolated from a retreating glacier in the Canadian High Arctic. Int J Syst Evol Microbiol 69:696-700

Tuna AL, Kaya C, Dikilitas M, Higgs D (2008) The combined effects of gibberellic acid and salinity on some antioxidant enzyme activities, plant growth parameters and nutritional status in maize plants. Environ Exp Bot 62:1-9

Tundo S, Paccanaro MC, Elmaghraby I, Moscetti I, D'Ovidio R, Favaron F et al. (2020) The Xylanase Inhibitor TAXI-I Increases Plant Resistance to Botrytis cinerea by Inhibiting the BcXyn11a Xylanase Necrotizing Activity. Plants 9:601

Turk M, Mejanelle L, Šentjurc M, Grimalt JO, GundeCimerman N, Plemenitaš A (2004) Salt-induced changes in lipid composition and membrane fluidity of halophilic yeast-like melanized fungi. Extremophiles 8:53-61

Urja P, Meenu S (2010) Role of single fungal isolates and consortia as plant growth promoters under saline conditions. Res J Biotechnol 5:5-9

Usha S, Padmavathi T (2013) Effect of plant growth promoting microorganisms from rhizosphere of Piper nigrum L. Int J Pharm Bio Sci 4:835-846

van Beelen P, Fleuren- Kemilä AK (1997) Influence of $\mathrm{pH}$ on the toxic effects of zinc, cadmium, and pentachlorophenol on pure cultures of soil microorganisms. Environ Toxicol Chem An Int $\mathrm{J}$ $16: 146-153$
Van Schöll L, Smits MM, Hoffland E (2006) Ectomycorrhizal weathering of the soil minerals muscovite and hornblende. New Phytol 171:805-814

Verma P, Yadav AN, Khannam KS, Saxena AK, Suman A (2017a) Potassium-solubilizing microbes: diversity, distribution, and role in plant growth promotion. In: Panpatte D.G., Jhala YK, Vyas RV, Shelat HN (eds) Microorganisms for Green Revolution: Volume 1: Microbes for Sustainable Crop Production. Springer Singapore, Singapore, pp 125-149. doi:10.1007/978981-10-6241-4_7

Verma P, Yadav AN, Kumar V, Singh DP, Saxena AK (2017b) Beneficial Plant-Microbes Interactions: Biodiversity of Microbes from Diverse Extreme Environments and Its Impact for Crop Improvement. In: Singh DP, Singh HB, Prabha R (eds) PlantMicrobe Interactions in Agro-Ecological Perspectives: Volume 2: Microbial Interactions and AgroEcological Impacts. Springer Singapore, Singapore, pp 543-580. doi:10.1007/978-981-10-6593-4_22

Vinale F, Sivasithamparam K, Ghisalberti EL, Marra R, Woo SL, Lorito M (2008) Trichoderma-plantpathogen interactions. Soil Biol Biochem 40:1-10

Viterbo A, Landau U, Kim S, Chernin L, Chet I (2010) Characterization of ACC deaminase from the biocontrol and plant growth-promoting agent Trichoderma asperellum T203. FEMS Microbiol lett 305:42-48

Wahid OAA, Mehana TA (2000) Impact of phosphatesolubilizing fungi on the yield and phosphorus-uptake by wheat and faba bean plants. Microbiol Res 155:221-227

Wang J, Chio C, Chen X, Su E, Cao F, Jin Y et al. (2019) Efficient saccharification of agave biomass using Aspergillus niger produced low-cost enzyme cocktail with hyperactive pectinase activity. Biores technol 272:26-33

Waqas M, Khan AL, Kamran M, Hamayun M, Kang SM, Kim Y-H et al. (2012) Endophytic fungi produce gibberellins and indoleacetic acid and promotes hostplant growth during stress. Molecules 17:1075410773

Waqas M, Khan AL, Shahzad R, Ullah I, Khan AR, Lee I-J (2015) Mutualistic fungal endophytes produce phytohormones and organic acids that promote japonica rice plant growth under prolonged heat stress. J Zhejiang Univ Sci B 16:1011-1018

Wei Z, Hillier S, Gadd GM (2012) Biotransformation of manganese oxides by fungi: solubilization and production of manganese oxalate biominerals. Environ Microbiol 14:1744-1753

Wilkinson S, Kudoyarova GR, Veselov DS, Arkhipova TN, Davies WJ (2012) Plant hormone interactions: 
innovative targets for crop breeding and management. J Exp Bot 63:3499-3509

Xia X, Lie TK, Qian X, Zheng Z, Huang Y, Shen Y (2011) Species diversity, distribution, and genetic structure of endophytic and epiphytic Trichoderma associated with banana roots. Microb Ecol 61:619-625

Xiao C-Q, Chi R-A, Huang X-H, Zhang W-X, Qiu G-Z, Wang D-Z (2008) Optimization for rock phosphate solubilization by phosphate-solubilizing fungi isolated from phosphate mines. Ecol Eng 33:187-193

Xu G, Wang J, Yin Q, Fang W, Xiao Y, Fang Z (2019) Expression of a thermo-and alkali-philic fungal laccase in Pichia pastoris and its application. Protein Exp Purif 154:16-24

Xu L, Wu C, Oelmüller R, Zhang W (2018) Role of phytohormones in Piriformospora indica-induced growth promotion and stress tolerance in plants: more questions than answers. Front Microbiol 9:1646

Yadav AN (2017) Agriculturally important microbiomes: biodiversity and multifarious PGP attributes for amelioration of diverse abiotic stresses in crops for sustainable agriculture. Biomed J Sci Tech Res 1:1-4

Yadav AN (2019) Fungal White Biotechnology: Conclusion and Future Prospects. In: Yadav AN, Singh S, Mishra S, Gupta A (eds) Recent Advancement in White Biotechnology Through Fungi: Volume 3: Perspective for Sustainable Environments. Springer International Publishing, Cham, pp 491-498. doi:10.1007/978-3-030-255060_20

Yadav AN, Kour D, Kaur T, Devi R, Yadav N (2020a) Agriculturally important fungi for crop productivity: Current research and future challenges. In: Yadav AN, Mishra S, Kour D, Yadav N, Kumar A (eds) Agriculturally Important Fungi for Sustainable Agriculture, Volume 1: Perspective for Diversity and Crop Productivity. Springer, Cham. doi:https://doi.org/10.1007/978-3-030-45971-0_12

Yadav AN, Kour D, Kaur T, Devi R, Yadav N (2020b) Functional annotation of agriculturally important fungi for crop protection: Current research and future challenges. In: Yadav AN, Mishra S, Kour D, Yadav N, Kumar A (eds) Agriculturally Important Fungi for Sustainable Agriculture, Volume 2: Functional Annotation for Crop Protection. Springer, Cham, pp $1-15$

Yadav AN, Kumar R, Kumar S, Kumar V, Sugitha T, Singh B et al. (2017a) Beneficial microbiomes: biodiversity and potential biotechnological applications for sustainable agriculture and human health. J Appl Biol Biotechnol 5:45-57

Yadav AN, Kumar V, Dhaliwal HS, Prasad R, Saxena AK (2018a) Microbiome in Crops: Diversity, 46
Distribution, and Potential Role in Crop Improvement. In: Prasad R, Gill SS, Tuteja N (eds) Crop Improvement Through Microbial Biotechnology.Elsevier: 305332.doi:https://doi.org/10.1016/B978-0-444-639875.00015-3

Yadav AN, Mishra S, Kour D, Yadav N, Kumar A (2020c) Agriculturally Important Fungi for Sustainable Agriculture, Volume 1: Perspective for Diversity and Crop Productivity. Springer International Publishing, Cham

Yadav AN, Rastegari AA, Yadav N, Kour D (2020d) Advances in Plant Microbiome and Sustainable Agriculture: Diversity and Biotechnological Applications. Springer, Singapore,

Yadav AN, Sachan SG, Verma P, Saxena AK (2015a) Prospecting cold deserts of north western Himalayas for microbial diversity and plant growth promoting attributes. J Biosci Bioeng 119:683-693

Yadav AN, Sachan SG, Verma P, Tyagi SP, Kaushik R, Saxena AK (2015b) Culturable diversity and functional annotation of psychrotrophic bacteria from cold desert of Leh Ladakh (India). World J Microbiol Biotechnol 31:95-108

Yadav AN, Singh J, Rastegari AA, Yadav N (2020e) Plant Microbiomes for Sustainable Agriculture.Springer (vol.25).

Yadav AN, Verma P, Kour D, Rana KL, Kumar V, Singh B et al. (2017b) Plant microbiomes and its beneficial multifunctional plant growth promoting attributes. Int J Environ Sci Nat Resour 3:1-8

Yadav AN, Verma P, Sachan SG, Kaushik R, Saxena AK (2018b) Psychrotrophic microbiomes: molecular diversity and beneficial role in plant growth promotion and soil health. In: Panpatte DG, Jhala YK, Shelat HN, Vyas RV (eds) Microorganisms for Green Revolution: Volume 2 : Microbes for Sustainable Agro-ecosystem. Springer Singapore, Singapore, pp 197-240. doi:10.1007/978-981-10-7146-1_11

Yadav AN, Yadav N (2018) Stress-adaptive microbes for plant growth promotion and alleviation of drought stress in plants. Acta Sci Agric (ISSN: 2581-365X) 2

Yadav BK, Sidhu AS (2016) Dynamics of Potassium and Their Bioavailability for Plant Nutrition. In: Meena VS, Maurya BR, Verma JP, Meena RS (eds) Potassium Solubilizing Microorganisms for Yuan Y, Feng H, Wang L, Li Z, Shi Y, Zhao L et al. (2017) Potential of endophytic fungi isolated from cotton roots for biological control against verticillium wilt disease. PLoS One 12:e0170557

Yadav M, Yadav A, Yadav JP (2014) In vitro antioxidant activity and total phenolic content of endophytic fungi isolated from Eugenia jambolana Lam. 
Asian Pac J Trop Med 7:S256-S261

Yamazaki A, Toyama K, Nakagiri A (2010) A new acidophilic fungus Teratosphaeria acidotherma (Capnodiales, Ascomycota) from a hot spring. Mycoscience 51:443-455

Yang XY, Zhang JX, Ding QY, He ZC, Zhu CY, Zhang KQ et al. (2020) Metabolites from Two Dominant Thermophilic Fungal Species Thermomyces lanuginosus and Scytalidium thermophilum. Chemi Biodiver 17:e2000137

Yao H, Sun X, He C, Maitra P, Li X-C, Guo L-D (2019) Phyllosphere epiphytic and endophytic fungal community and network structures differ in a tropical mangrove ecosystem. Microbiome 7:57

Yehia RS, Osman GH, Assaggaf H, Salem R, Mohamed MS (2020) Isolation of potential antimicrobial metabolites from endophytic fungus Cladosporium cladosporioides from endemic plant Zygophyllum mandavillei. South African Journal of Botanydoi:https://doi.org/10.1016/j.sajb.2020.02.033.

Zeng X, Liu X, Tang J, Hu S, Jiang P, Li W et al. (2012) Characterization and potassium-solubilizing ability of Bacillus Circulans Z 1-3. Adv Sci Lett 10:173176
Zhang Y, Chen F-S, Wu X-Q, Luan F-G, Zhang L-P, Fang X-M et al. (2018a) Isolation and characterization of two phosphate-solubilizing fungi from rhizosphere soil of moso bamboo and their functional capacities when exposed to different phosphorus sources and $\mathrm{pH}$ environments. PloS one 13

Zhang Y, Chen F-S, Wu X-Q, Luan F-G, Zhang L-P, Fang X-M et al. (2018b) Isolation and characterization of two phosphate-solubilizing fungi from rhizosphere soil of moso bamboo and their functional capacities when exposed to different phosphorus sources and $\mathrm{pH}$ environments. PloS one 13:e0199625

Zhang Y-Q, Sun Y-X, Ye Y-L, Karim MR, Xue Y-F, Yan $P$ et al. (2012) Zinc biofortification of wheat through fertilizer applications in different locations of China. Field Crops Res 125:1-7 